\title{
Influence of Various Treatments on Textural Profile Analysis of Indian Gooseberry (Emblica officinalis) Candy during Storage
}

\author{
B. Ghanwat Archana*, V.S. Khandare and S.J. Syed \\ Department of Horticulture, Vasantrao Naik Marathwada Krishi Vidyapeeth, \\ Parbhani-431 402, (M.S.), India \\ *Corresponding author
}

\begin{tabular}{|l|}
\hline Ke y w or d s \\
$\begin{array}{l}\text { Aonla, Sugar syrup, } \\
\text { Candy, Drying } \\
\text { methods, Texture }\end{array}$ \\
\hline Article Info \\
\hline $\begin{array}{l}\text { Accepted: } \\
\text { 04 July } 2019 \\
\text { Available Online: } \\
\text { 10 August } 2019\end{array}$ \\
\hline
\end{tabular}

A B S T R A C T

The present investigation was carried out during 2015-16, in the Department of Horticulture, V.N.M.K.V. Parbhani, Maharashtra. Aonla (Emblica officinalis) also known as Indian gooseberry is one of the oldest Indian fruits and considered as "Wonder fruit for health". The aonla candy was made up by using different treatments i.e. sugar syrup solutions, dipping time and drying methods. There are two levels of sugar syrup concentrations i.e. $60 \%$ and $70 \%$, three dipping times i.e. $36 \mathrm{hrs}, 42 \mathrm{hrs}$ and $48 \mathrm{hrs}$ and three drying methods i.e. sun drying, solar drying and cabinet drying. Candy was prepared by combining these treatments. Eighteen treatment combinations were taken in factorial combined randomized design with three replications. The treatment $S_{1} T_{2} M_{2}$ showed the highest values for hardness $(43.278 \mathrm{~kg})$. The hardness was found to be less in treatment $S_{2} T_{2} M_{3}\left(20.720 \mathrm{~kg}\right.$.). The treatment $S_{2} T_{2} M_{1}$ showed lowest value of cohesiveness (0.140) and treatment $S_{1} T_{1} M_{3}$ showed the highest value (1.384). The highest springiness value (1.172) was found in $S_{1} T_{3} M_{2}$ and treatment $\mathrm{S}_{2} \mathrm{~T}_{2} \mathrm{M}_{1}$ showed lowest value i.e. 0.996. Moreover, adhesiveness was found to be highest in treatment $S_{2} T_{2} M_{1}$ i.e. 0.297 and least in treatment $S_{1} T_{1} M_{3}$ i.e. 0.037. Use of Cabinet dryer during candy preparation showed more overall acceptability than sun and solar dryer. High sugar concentration imparted good colour, appearance and texture to aonla candy sensory basis.

\section{Introduction}

Aonla (Emblica officinalis) is one of the unique fruit which has got great importance because of its high antioxidant and medicinal properties. Aonla (Emblica officinalis) or Indian gooseberry belongs to family Euphorbiaceae and is indigenous to tropical South East Asia, particularly in Central and
Southern India (Parmar and Kaushal, 1982) from where it spread to Sri Lanka, Malaysia and China (Bose et al., 2002). India ranks first in the world with respect to area and production of cultivated aonla (Priya and Khatkar, 2013). The estimated production of aonla in the country during the year 2014-15 was 1319 thousand tonnes from an area of 107 thousand whereas, in HP its production has 
been estimated as 2390 MT from an area of 2158 ha (Anonymous, 2015). It is widely distributed in Uttar Pradesh, Maharashtra, Gujarat, Rajasthan, Andhra Pradesh, Karnataka, Tamil Nadu, Haryana and Himachal Pradesh. Although the wild aonla is widely distributed in the forests of HP up to an elevation of $1450 \mathrm{~m}$ above mean sea level (Parmar and Kaushal, 1982), but there are no records of its area and production. Aonla fruit is a rich source of ascorbic acid, phenols, sugars, pectin, starch and mineral like iron, calcium, phosphorous and magnesium (Nath et al., 1992). Being rich source of ascorbic acid, it contains about 20 times more vitamin C than the citrus fruits (Parmar and Kaushal, 1982). Its fruits are astringent, carminative, digestive, stomachic, diuretic and antipyretic and also useful in curing many diseases like diabetes, cough, asthma, bronchitis, headache, ophthalmic disorders, dyspepsia, colic, flatulence, skin diseases, leprosy, jaundice, scurvy, diarrhoea and greyness of hair (Ganachari et al., 2010). It also contains leucoanthocyanins along with polyphenols which maintain the stability of ascorbic acid as well as astringency of the fruit (Radha and Mathew, 2007). Tannins (gallic acid and elagic acid) and glucose render its value as antiscorbutic in fresh as well as dried conditions (Pareek and Kaushik, 2012). Due to its high astringency and perishable nature after harvest aonla fruits are not popular as table fruit (Kumar and Nath, 1993). Being highly perishable nature of cultivated aonla, it has limited period of availability under north Indian conditions (Bhattacherjee et al., 2012). But scattered information is available in the literature with respect to the development of value added products from wild aonla. So, in view of its availability in abundance and various health benefits there is need to make use of this wild fruit for the development of various value added products. Keeping in view the availability of this fruit in the forests of HP and importance with respect to its quality characteristics, the present studies were carried out with the following objectives to develop preserve from wild aonla fruits and its quality evaluation during storage. According to FSSAI, 2006 preserve means the product prepared from sound, whole, cut or grated fruits, rhizomes or vegetables, singly or in combination, by impregnating it with sweeteners to an adequate concentration to preserve it. According to FSSAI, 2006 preserve contains at least 55 per cent fruit part and $68{ }^{\circ} \mathrm{B}$ TSS.

\section{Materials and Methods}

The aonla candy was made up by using different treatments i.e. sugar syrup solutions, dipping time and drying methods. There are two levels of sugar syrup concentrations and three dipping times and 3 drying methods i.e. sun drying, solar drying and cabinet drying. The details of materials used and methods adopted for the conduct of experiment are presented in this chapter under appropriate headings.

\section{Procurement of aonla fruits}

The fully mature aonla fruits were procured from the local market of Parbhani district of Maharashtra. The fruits were graded and washed thoroughly with continuous stream of water to remove adherent dirt particles and other foreign materials. Good quality crystal sugar and alum were purchased from local market and used for the preparation of aonla candy.

\section{Equipment's and Instruments}

Different equipment required for the preparation of aonla candy and for various physico-chemical characterization such as solar dryer, cabinet dryer, hand refractometer, texture analyzer etc. were made available from the Department of Utilization of animal 
energy, Department of Horticulture and College of Food Technology, VNMKV, Parbhani.

\section{Packaging materials}

The suitable packaging materials such as polyethylene bags (LDPE) of 200 guage and standing pouch (composite layers of Polyamide and Nylon) of 250 guage were obtained from local market of Parbhani.

\section{Materials and Methods}

\section{Processing of aonla}

\section{Washing}

Aonla fruits were washed thoroughly with clean running water to remove dirt or other foreign materials.

\section{Blanching}

Aonla fruits were tied loosely in a muslin cloth bag and dipped in boiling water for 5 to 7 minutes to soften the fruits for easy separation of segments. Then seeds were removed and segments were separated as suggested by Kumar et al., (2001). The blanched segments were steeped in 2\% Alum solution for $12 \mathrm{hrs}$. After steeping in alum solution the segment was washed to remove the traces of alum. The product was prepared by dipping the segments in successive increasing concentrations of sugar syrup at room temperature till equilibrium at $70^{\circ}$ brix was reached as per the method described by Tondon et al., (2006). Firstly 50\% brix sugar syrup was prepared to which pre-treated segments were transferred. After soaking for 24 hours, the segments were taken out and shifted to $60^{\circ}$ brix for further 24 hours. On the next day, the same syrup was boiled to the concentration $70^{\circ}$ brix, which was cooled and transferred to the fruit segments which were kept for next 3 days. On the fourth day, the osmosed segments were separated out from syrup and dipped in water for $30 \mathrm{sec}$. thoroughly to remove surface syrup to avoid stickiness. Drying was carried out by various types of dryers viz. Sun drying, solar drying, cabinet drying. When the sufficiently dry and leathery texture was achieved, product was removed from dryer and immediately packed in polyethylene bags, sealed and stored for further studies.

\section{Textural profile analysis}

Stable Micro System TAXT2 plus Texture Analyzer was used for texture profile analysis (TPA) of aonla Candy. TPA is "two-bite" test, which includes the first and second compression cycles. The first and second compression cycles indicate the force vs. time data during the first and second compression of the product by the instrument probe. Representative graphs of texture analysis are obtained. The parameters recorded were hardness, fracturability, springiness, cohesiveness and gumminess. The test is configured so that the TPA parameters, hardness, fracturability, springiness, cohesiveness and gumminess were calculated at the time of the test by determining the load and displacement at predetermined points on the TPA curve Hardness (F1) was the maximum load, expressed in $\mathrm{kg}$, applied to the samples during the first compression. Fracturability point occurs where the plot has its first significant peak (where the force falls off) during the probe's first compression of the product. Compressiveness (A2/A1) was the ratio of the area under the curve for the second compression (A2) to that under the first compression (A1). Adhesiveness (A3) was the area under negative peak and expressed as $\mathrm{kg} / \mathrm{second}$. Gumminess (F1xA2/A1) was the product of hardness and cohesiveness. It was expressed as $\mathrm{kg}$. There were three replications of the instrumental 
analysis conducted on three separate days. Instrumental TPA test was carried out by a compression test that generates plot of force (N) versus time(S) using a textural analyzer equipped with a 5-kg load cell. The analyzer was linked to a computer that recorded data via a software programme. A 75-mm diameter cylindrical plate was used to measure textural properties. The samples $(0.5 \times 0.5 \times 0.5 \mathrm{~cm})$ were taken and compressed up to $75 \%$ of their original height at a speed of $0.5 \mathrm{~mm} / \mathrm{s}$ with a pre-test and post-test speed of $1 \mathrm{~mm} / \mathrm{s}$ and $5 \mathrm{~mm} / \mathrm{s}$, respectively. The data obtained from the TPA curve were used for the calculation of textural parameters (hardness, fracturability, cohesiveness, springiness and chewiness).

\section{Statistical analysis}

All processing equipment's and analysis of samples were run in triplicate. Analysis of variance was calculated using standard ANOVA procedure. The data obtained for various treatments was recorded and statistically analyzed by Factorial complete randomized design (FCRD) to find out the level of significance as per the method proposed by Panse and Sukhatme (1967).

\section{Results and Discussion}

Effect of drying methods on quality of aonla candy

The results relating to the dehydration of aonla candy with respect to sugar syrup concentration, dipping time and drying methods are presented below.

\section{Drying Kinetics}

Typical drying curves of aonla candy under convective air drying conditions at $60^{\circ} \mathrm{C}$ temperatures are shown in Fig.7-12. The moisture content versus time curves for drying at $60^{\circ} \mathrm{C}$ of aonla candy are shown in Fig.1-6.
A general trend observed was that with increase in drying time there was a gradual decrease in moisture content. The initial moisture content of aonla candy was $70 \%$. It nearly took 4 hours to achieve $50 \%$ moisture level at $60^{\circ} \mathrm{C}$ temperature in cabinet dryer. The subsequent drying pattern being slow, additional $3 \mathrm{hrs}$ at $60^{\circ} \mathrm{C}$ temperatures was required for the samples to reach the EMC. The total time required to dry aonla candy from an initial moisture content of $70 \%$ to EMC at $60^{\circ} \mathrm{C}$ in sun drying, solar drying and cabinet drying was $19 \mathrm{hrs}, 12 \mathrm{hrs}$ and $7 \mathrm{hrs}$ respectively.

\section{Effect of different treatments on Texture Profile of aonla candy}

The texture of any product plays a very important role in determining the acceptability. Texture Profile Analysis (TPA) of aonla candy was assessed using a texture analyser. The values are summarized in table 1 showed instrumental texture profiles of aonla candy of different sugar solution concentration, dipping time and different methods of drying. Their graphs are depicted in the figures 13-31.

The highest values of hardness $(43.278 \mathrm{~kg})$ were recorded in treatment $S_{1} T_{2} M_{2}$ followed by in treatment $\mathrm{S}_{1} \mathrm{~T}_{1} \mathrm{M}_{2}(39.166 \mathrm{~kg})$. The hardness of aonla candy treated with $60 \%$ sugar syrup concentration was found harder than aonla candy treated with $70 \%$ sugar syrup concentration. The lowest value of hardness of aonla candy was found in treatment $\mathrm{S}_{2} \mathrm{~T}_{2} \mathrm{M}_{3}$ $(20.720 \mathrm{~kg})$. The mean value of hardness of aonla candy was 30.507 .

Hardness values of samples with less sugar syrup concentration were found to be more than higher sugar syrup concentration. The work on firmness has been carried out by Phisut et al., (2013) during investigation of cantaloupes. 
Fig.1 Effect of different treatment $\left(\mathrm{S}_{1} \mathrm{~T}_{1} \mathrm{M}_{1}\right)$ on per cent moisture content of aonla candy

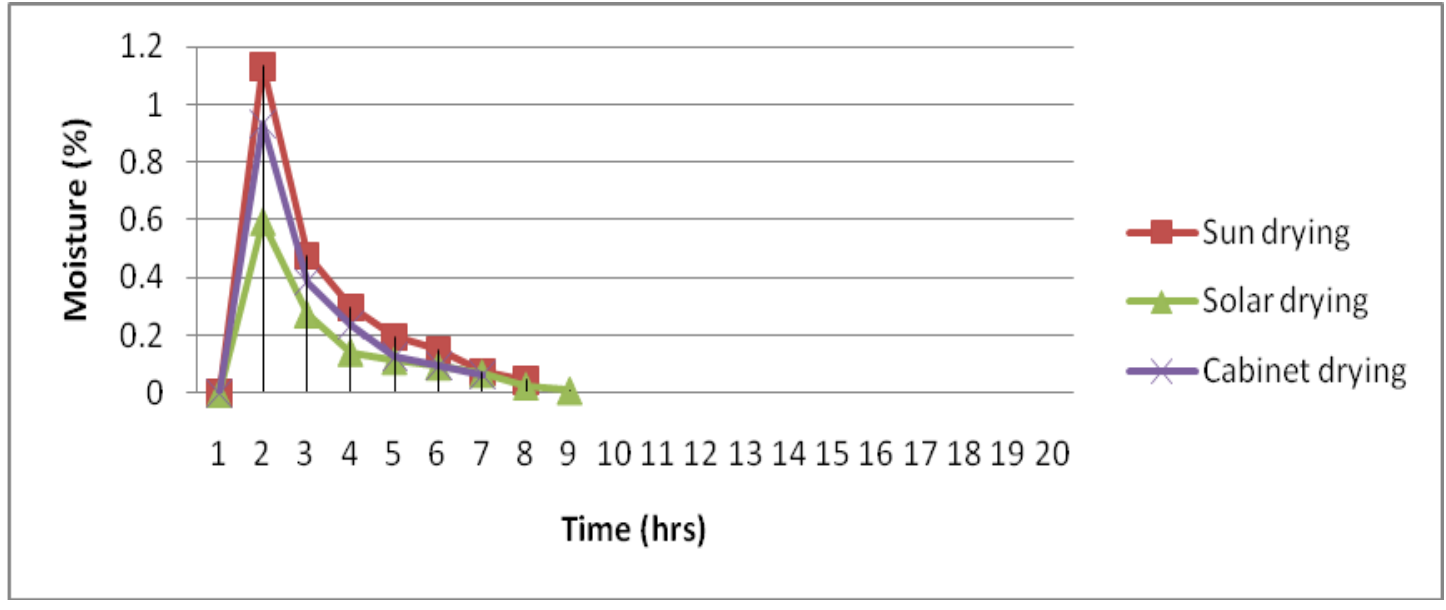

Fig.2 Effect of different treatment $\left(\mathrm{S}_{1} \mathrm{~T}_{1} \mathrm{M}_{2}\right)$ on per cent moisture content of aonla candy

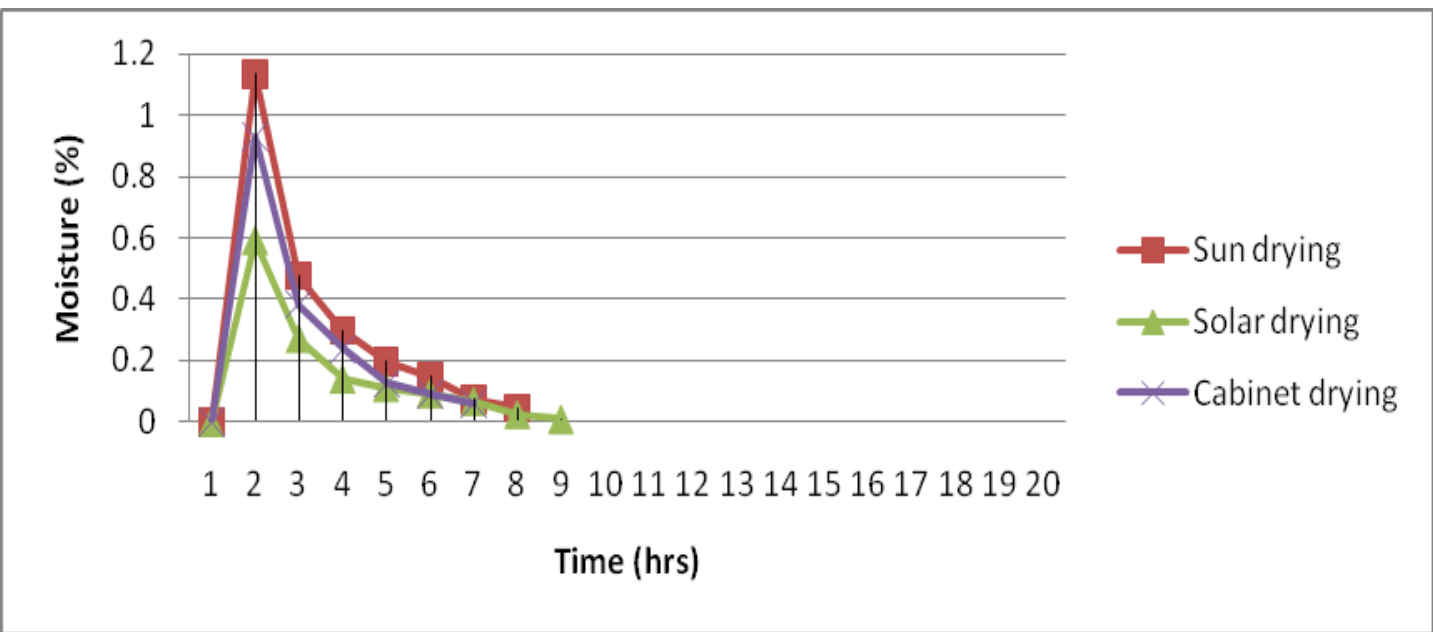

Fig.3 Effect of different treatment $\mathrm{S}_{1} \mathrm{~T}_{1} \mathrm{M}_{3}$ ) on per cent moisture content of aonla candy

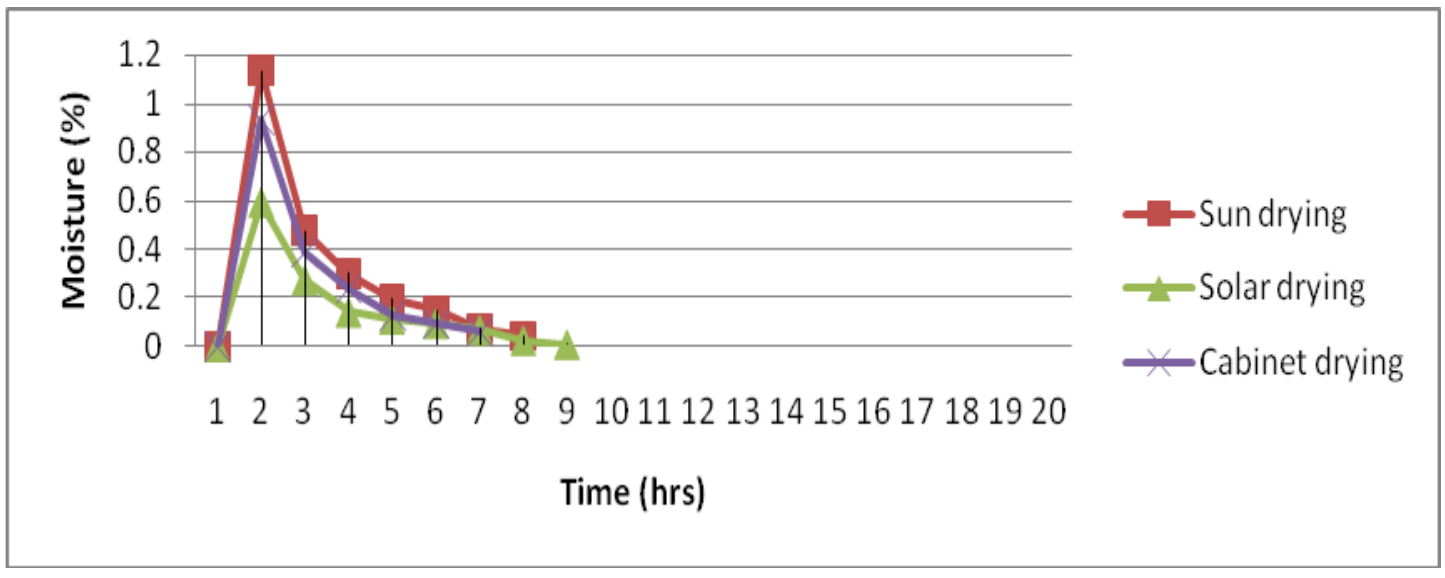


Fig.4 Effect of different treatment $\left(\mathrm{S}_{2} \mathrm{~T}_{2} \mathrm{M}_{1}\right)$ on per cent moisture content of aonla candy

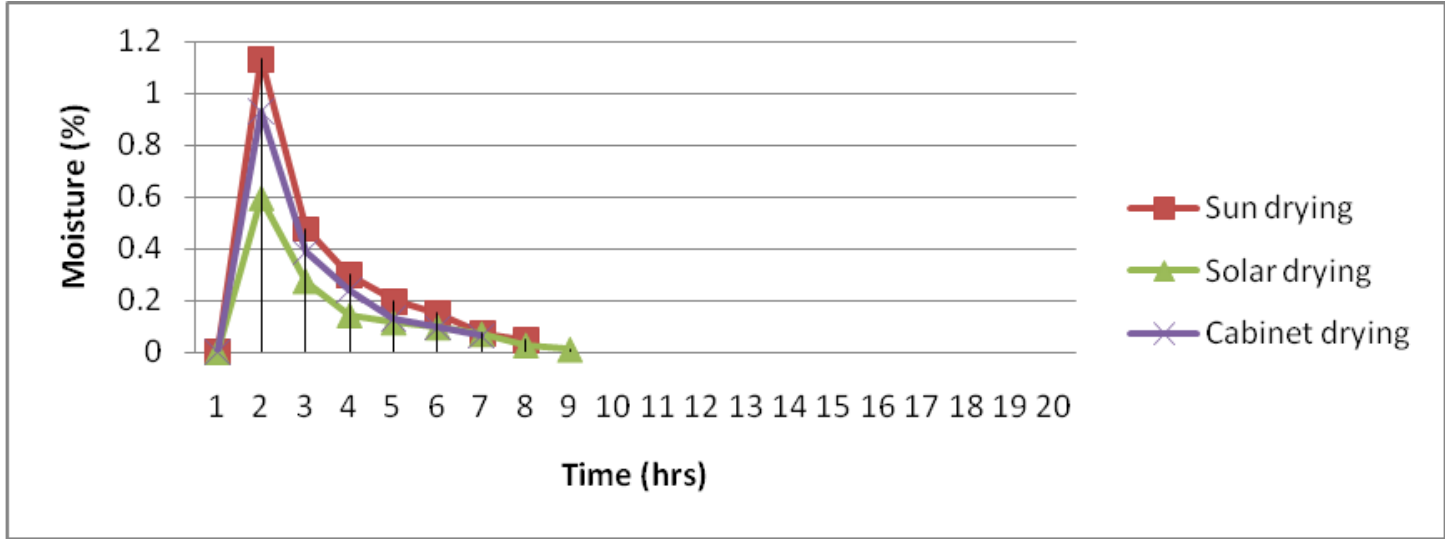

Fig.5 Effect of different treatment $\left(\mathrm{S}_{2} \mathrm{~T}_{2} \mathrm{M}_{2}\right)$ on per cent moisture content of aonla candy

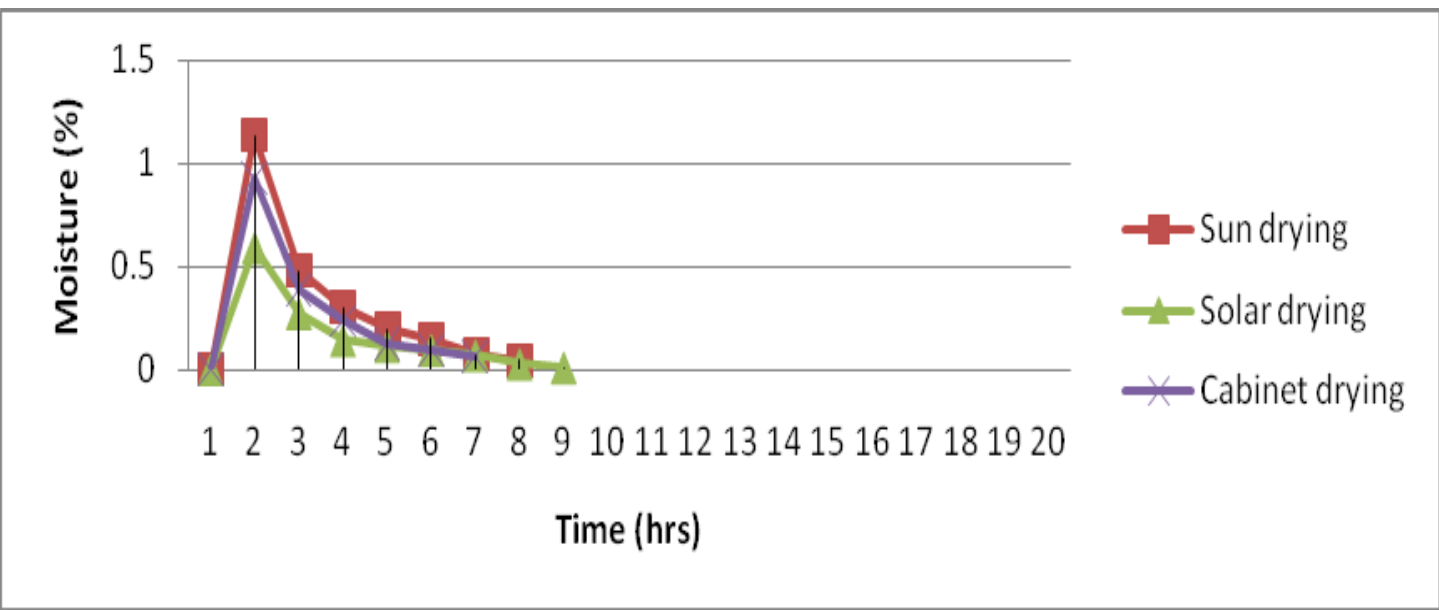

Fig.6 Effect of different treatment $\left(\mathrm{S}_{2} \mathrm{~T}_{2} \mathrm{M}_{3}\right)$ on per cent moisture content of aonla candy

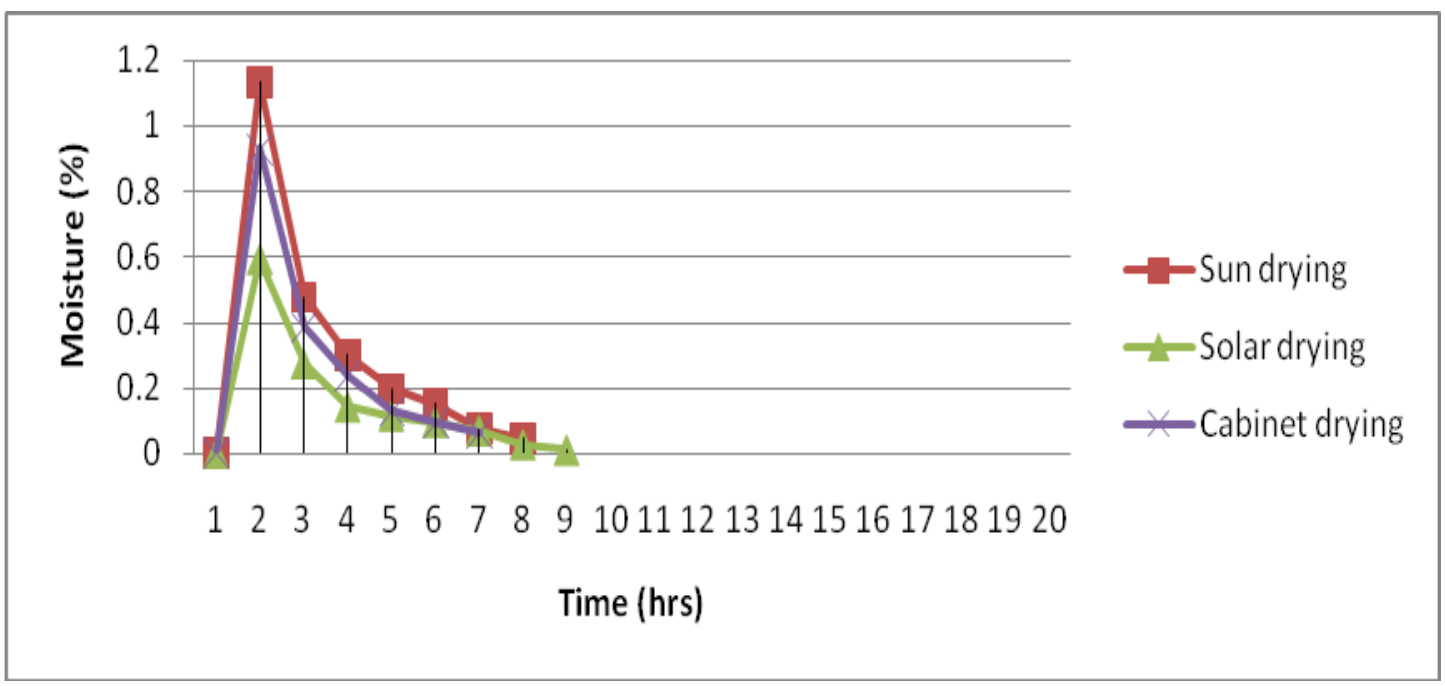


Fig.7 Effect of different treatment $\left(\mathrm{S}_{1} \mathrm{~T}_{1} \mathrm{M}_{1}\right)$ on drying rate of aonla candy

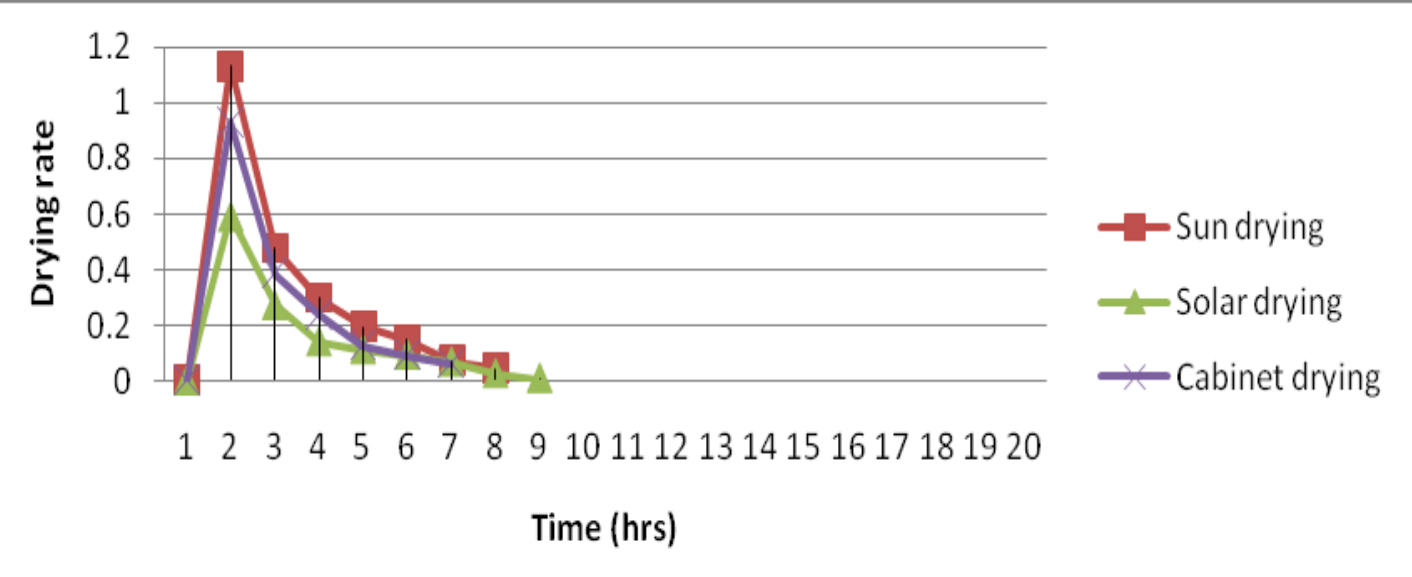

Fig.8 Effect of different treatment $\left(\mathrm{S}_{1} \mathrm{~T}_{1} \mathrm{M}_{2}\right)$ on drying rate of aonla candy

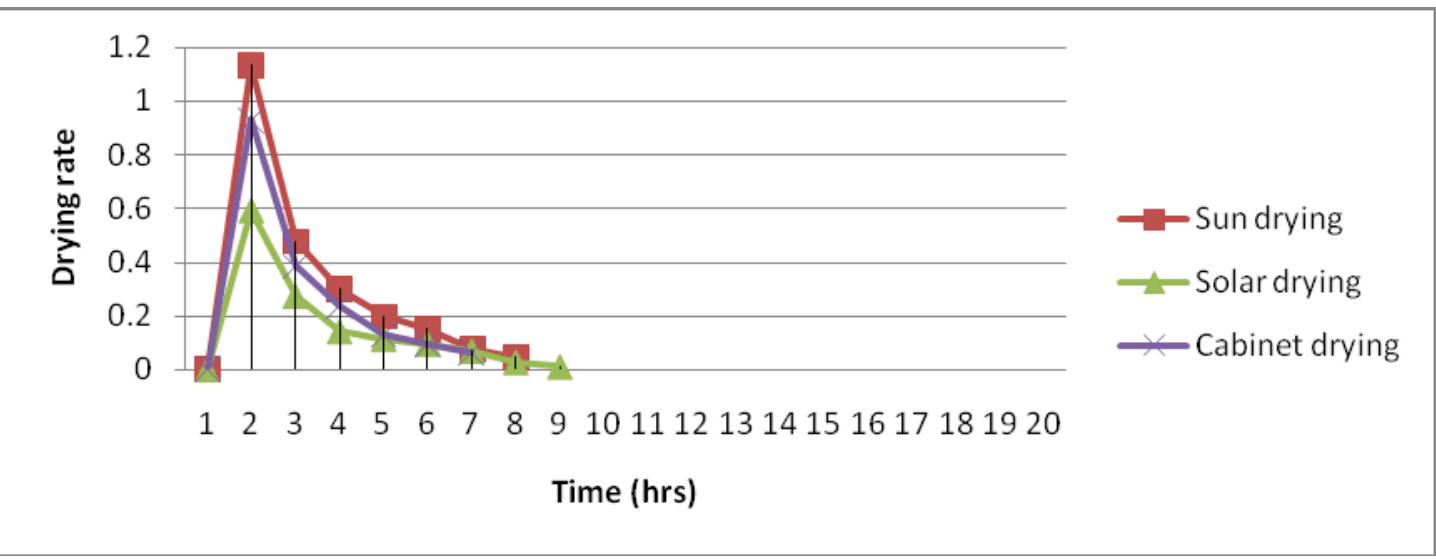

Fig.9 Effect of different treatment $\left(\mathrm{S}_{1} \mathrm{~T}_{1} \mathrm{M}_{3}\right)$ on drying rate of aonla candy

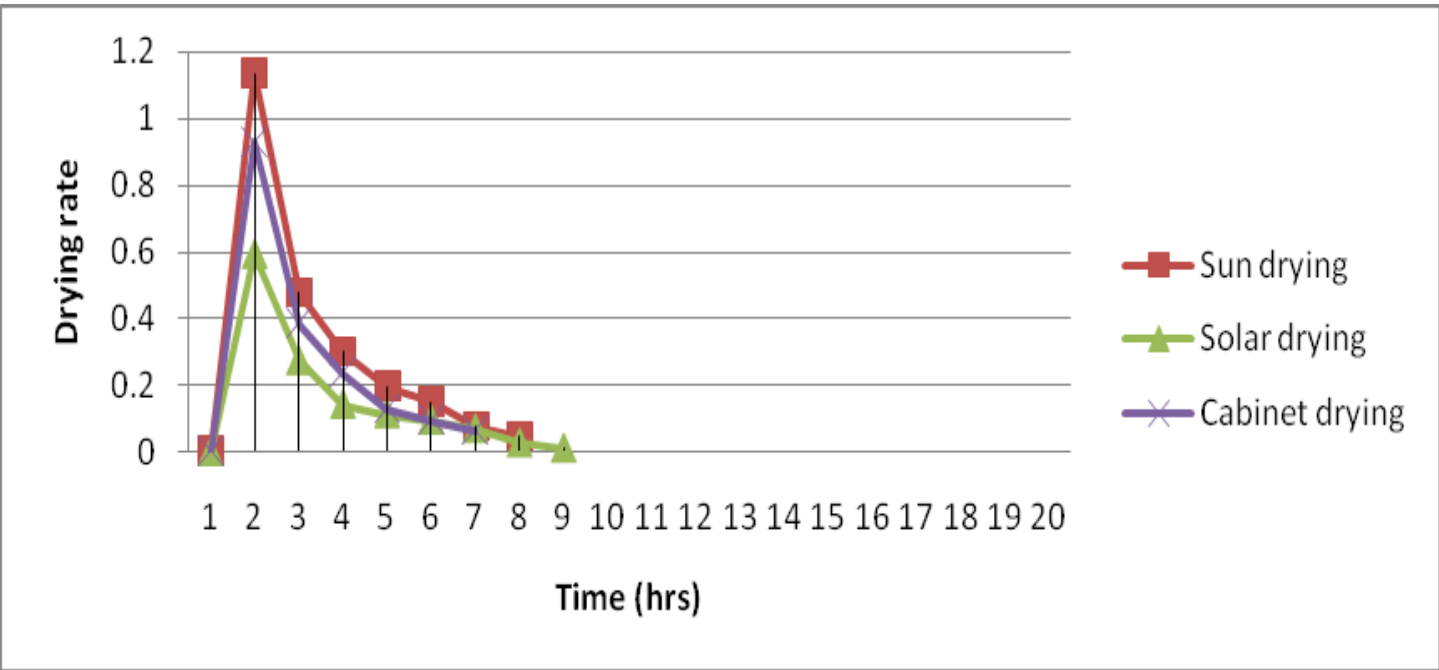


Fig.10 Effect of different treatment $\left(\mathrm{S}_{2} \mathrm{~T}_{1} \mathrm{M}_{1}\right)$ on drying rate of aonla candy

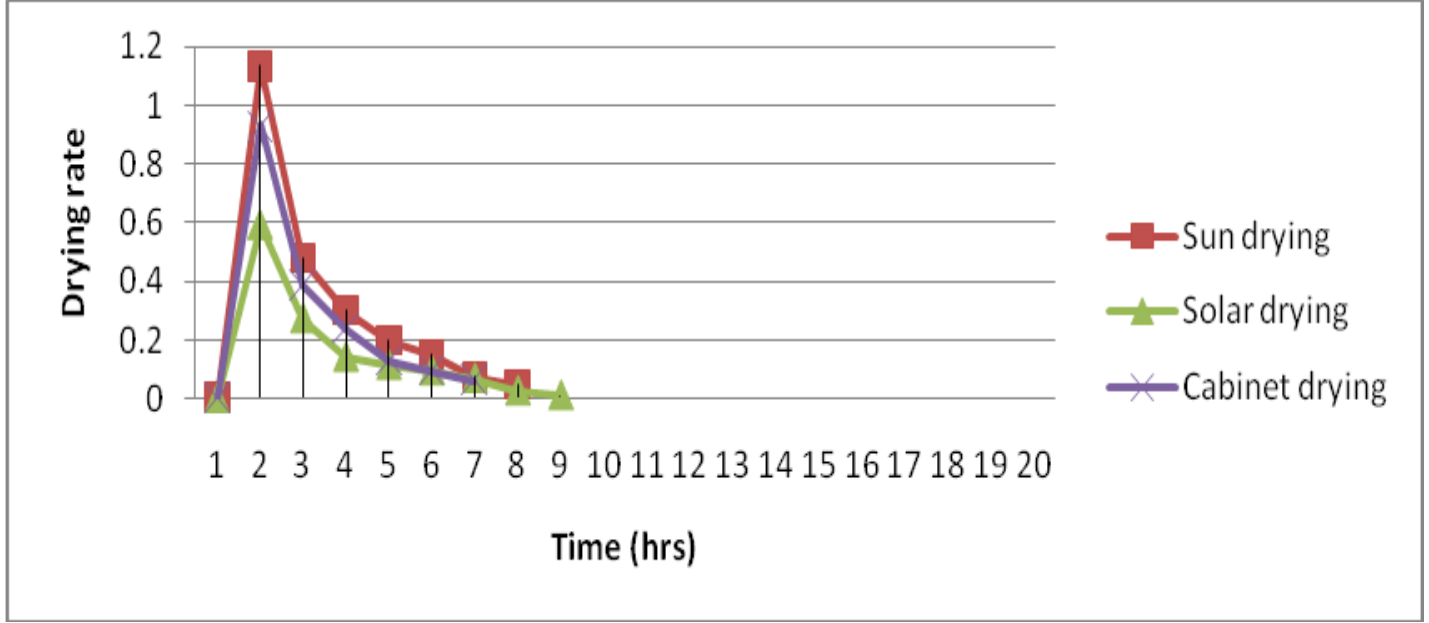

Fig.11 Effect of different treatment $\left(\mathrm{S}_{2} \mathrm{~T}_{2} \mathrm{M}_{2}\right)$ on drying rate of aonla candy

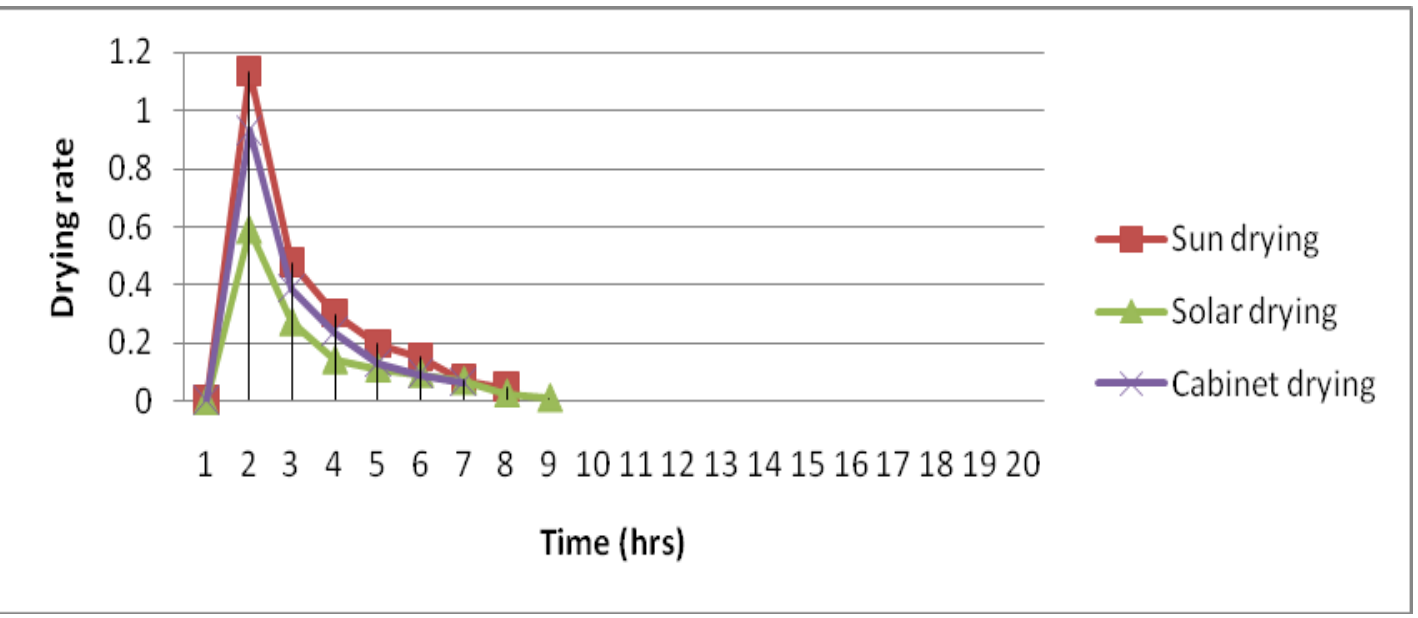

Fig.12 Effect of different treatment $\left(\mathrm{S}_{2} \mathrm{~T}_{2} \mathrm{M}_{3}\right)$ on drying rate of aonla candy

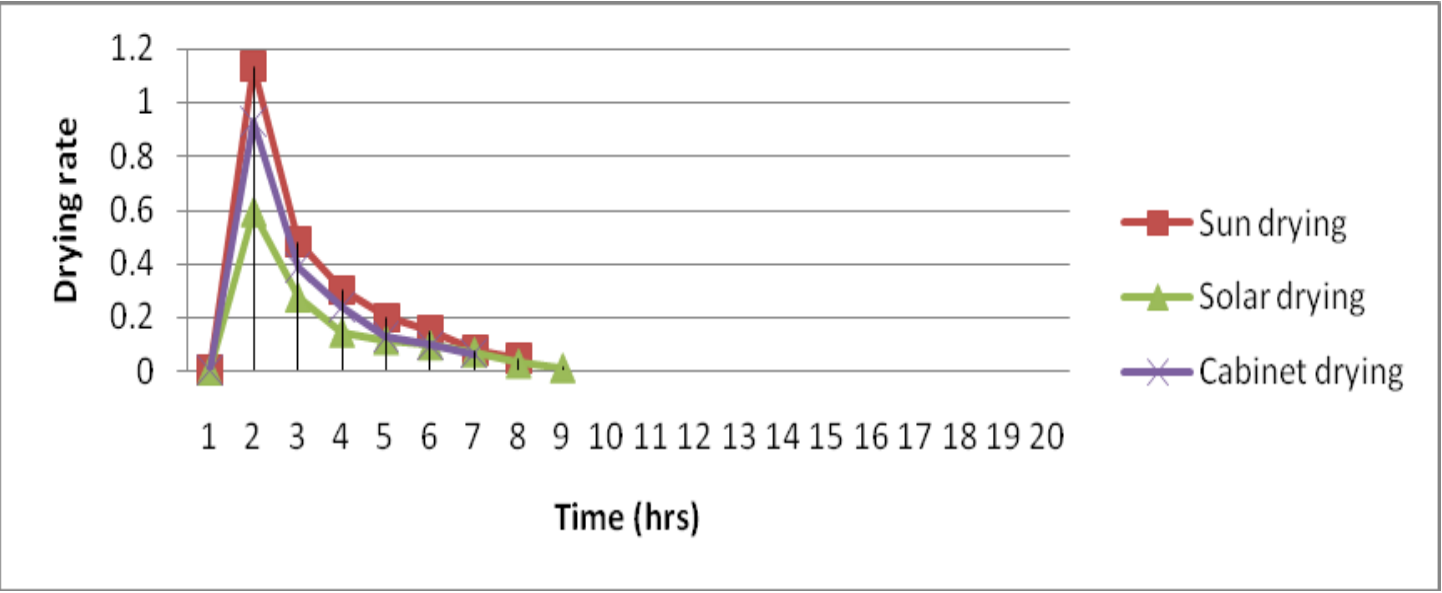


Fig.13 Representative graph of Texture Profile Analysis (TPA) of aonla candy

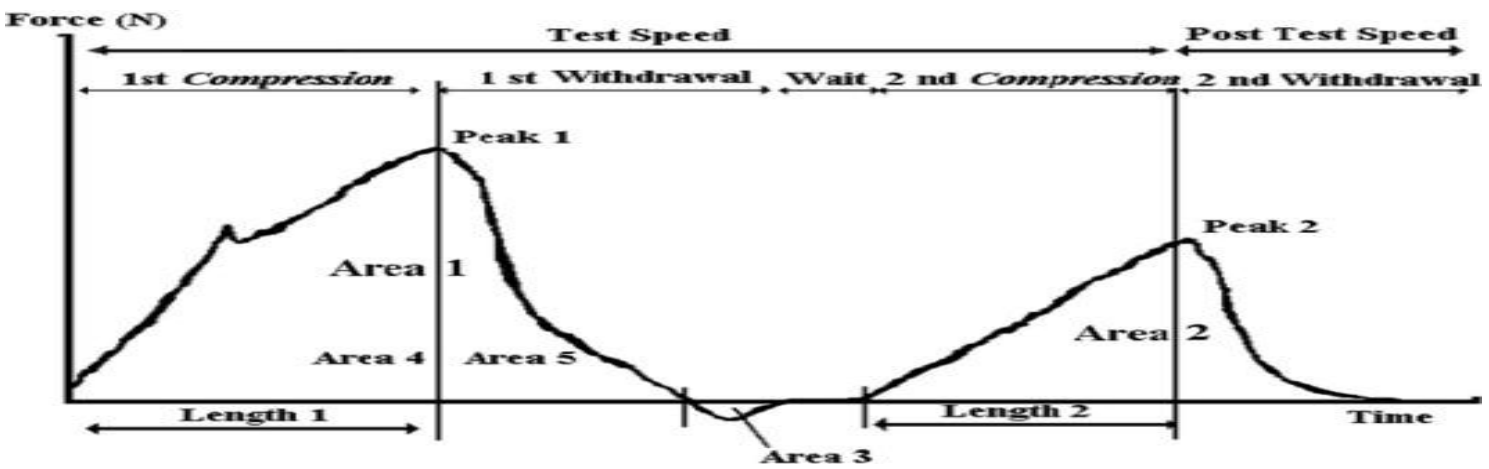

Hardness $(\mathrm{kg})=\mathrm{F} 1$

Cohesiveness $=\mathrm{A} 2 / \mathrm{A} 1$

Adhesiveness $(\mathrm{kg}-\mathrm{sec})=\mathrm{A} 3$

Gumminess $(\mathrm{kg})=$ Hardness $\mathrm{X}$ Cohesiveness

Springiness $=\mathrm{L} 2 / \mathrm{L} 1$

Where, F1- Positive Peak Force (Cycle 1)

F2- Peak Force (Cycle 2)

A1- Positive Area (Cycle 1)

A2- Positive Area (Cycle 2)

A3- Peak Negative Force

L1 - Length of Cycle 1

L2 - Length of Cycle 2

Fig.14 TPA graph aonla candy $\left(\mathrm{S}_{1} \mathrm{~T}_{1} \mathrm{M}_{1}\right)$

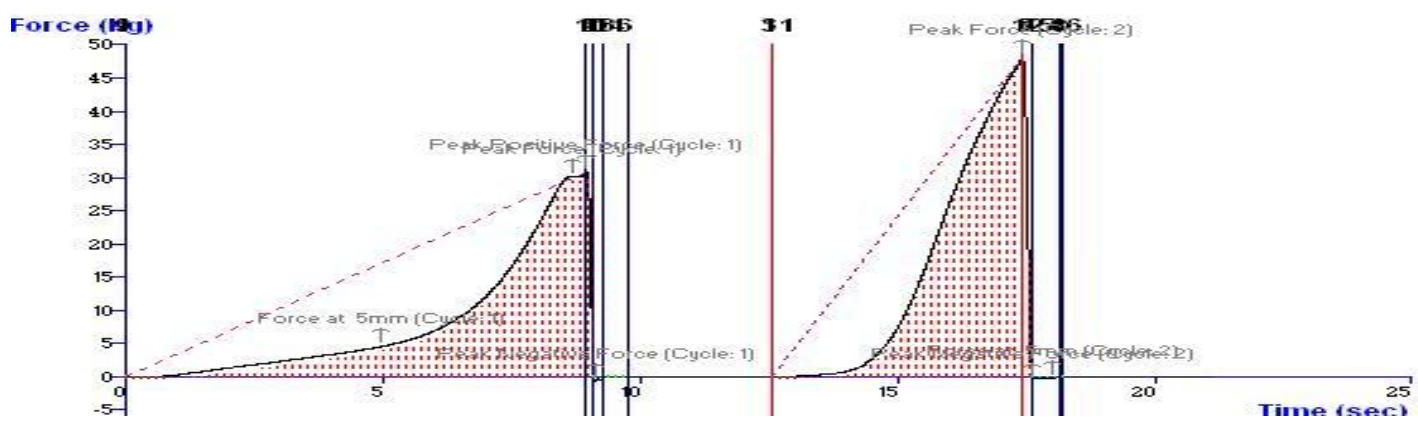

S1-T1-M1

Fig.15 TPA graph aonla candy $\left(\mathrm{S}_{1} \mathrm{~T}_{1} \mathrm{M}_{2}\right)$

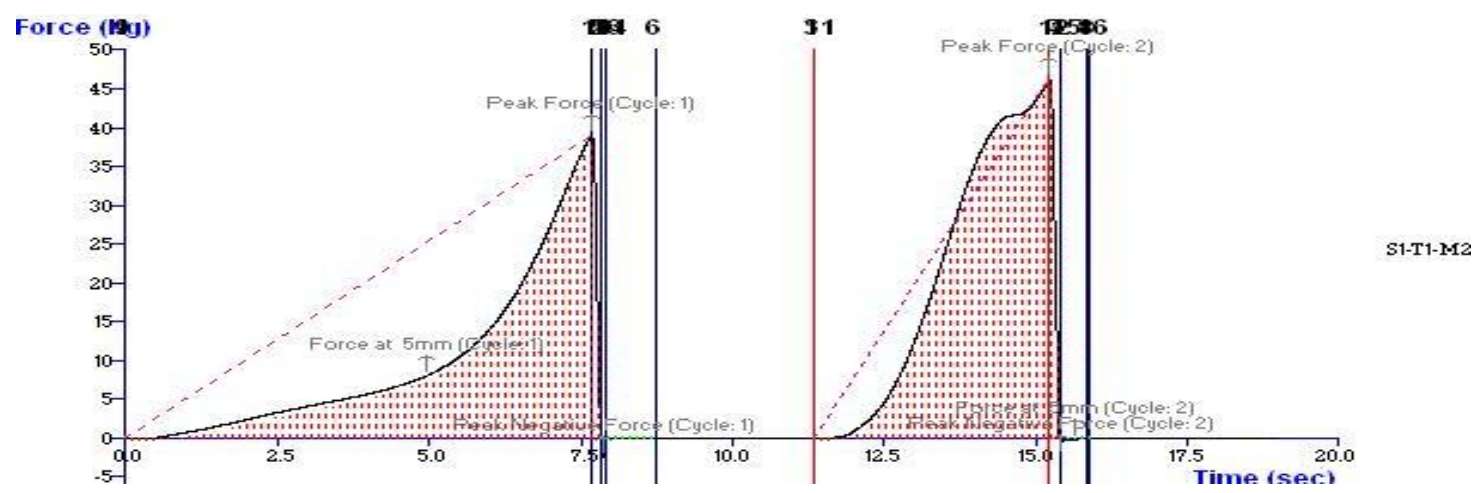


Fig.16 TPA graph aonla candy $\left(\mathrm{S}_{1} \mathrm{~T}_{1} \mathrm{M}_{3}\right)$

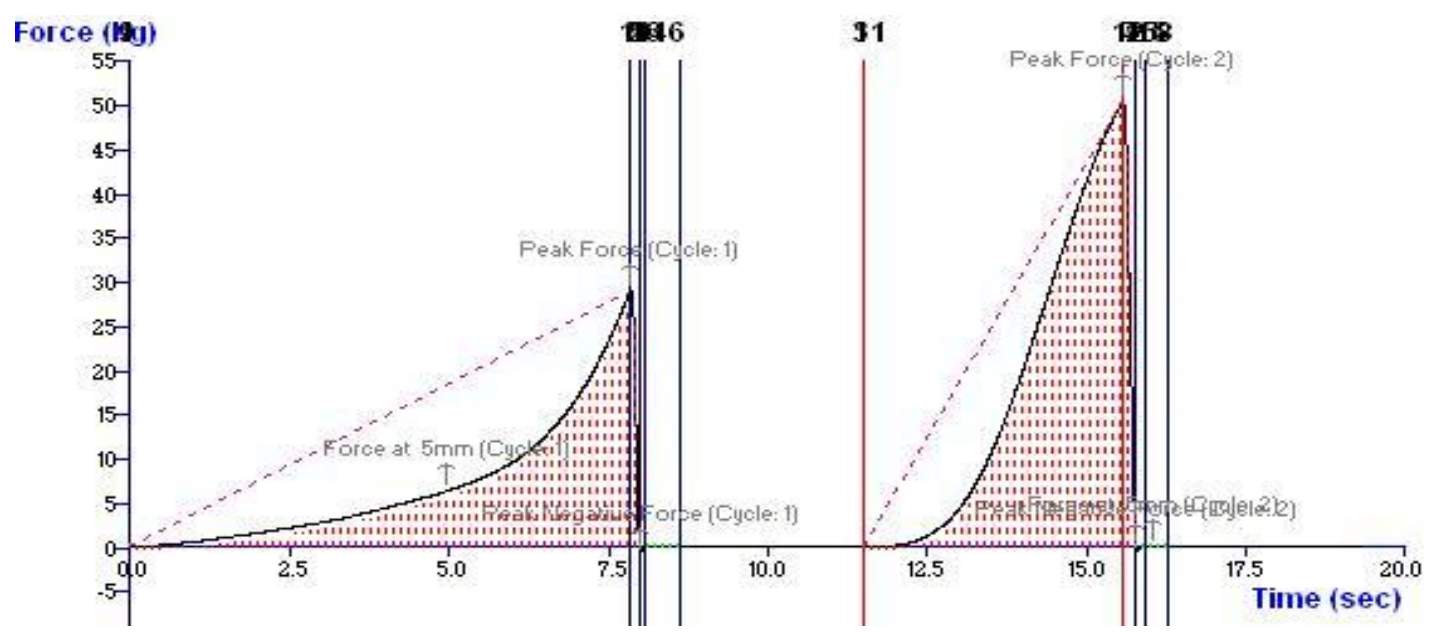

Fig.17 TPA graph aonla candy $\left(\mathrm{S}_{1} \mathrm{~T}_{2} \mathrm{M}_{1}\right)$

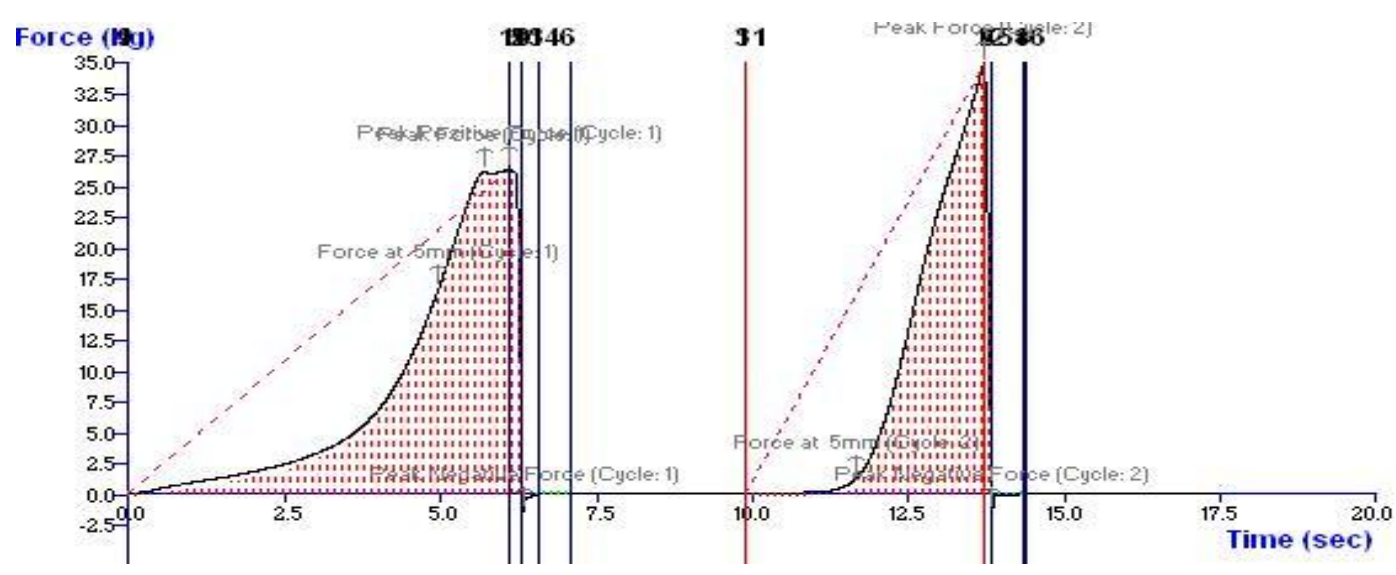

Fig.18 TPA graph aonla candy $\left(\mathrm{S}_{1} \mathrm{~T}_{2} \mathrm{M}_{2}\right)$

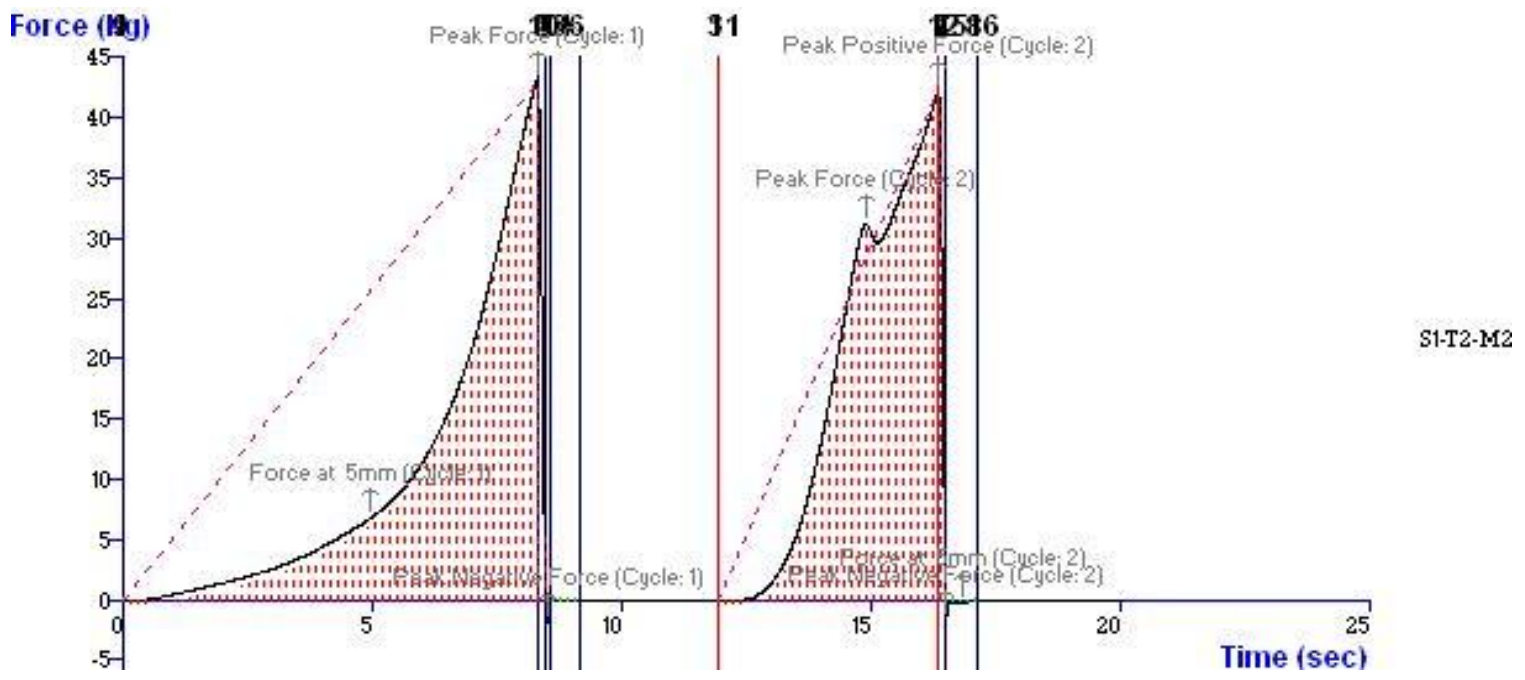


Fig.19 TPA graph aonla candy $\left(\mathrm{S}_{1} \mathrm{~T}_{2} \mathrm{M}_{3}\right)$

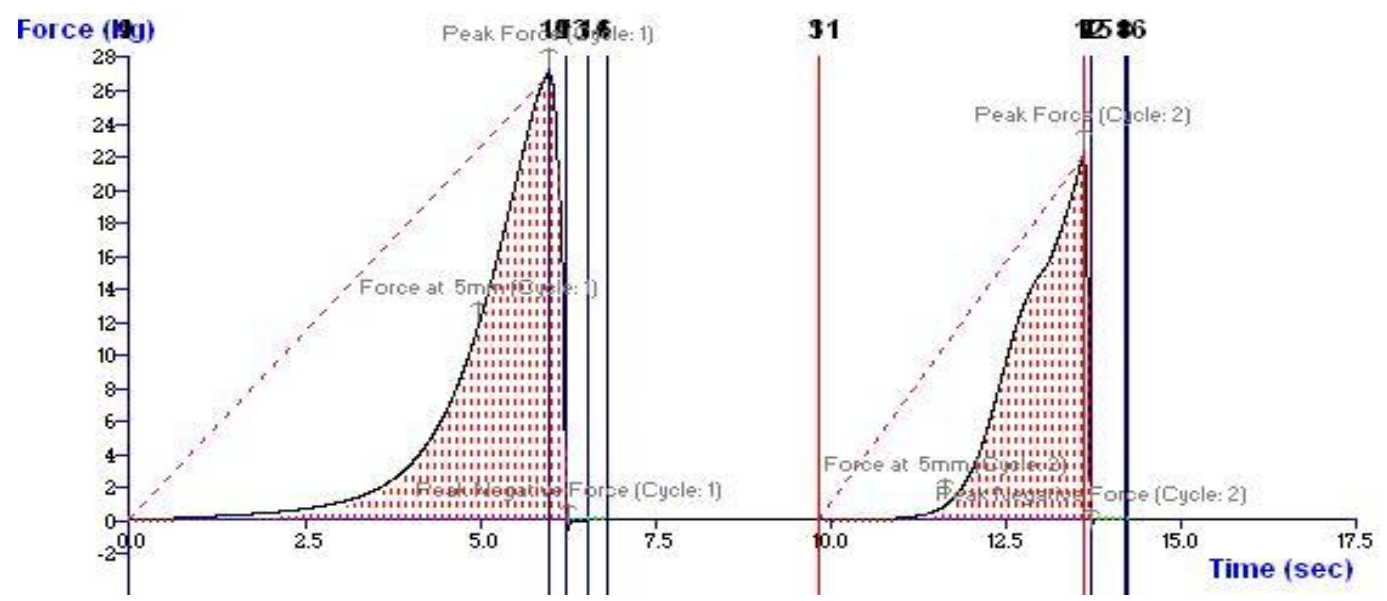

S1-T2-M3

Fig.20 TPA graph aonla candy $\left(\mathrm{S}_{1} \mathrm{~T}_{3} \mathrm{M}_{1}\right)$

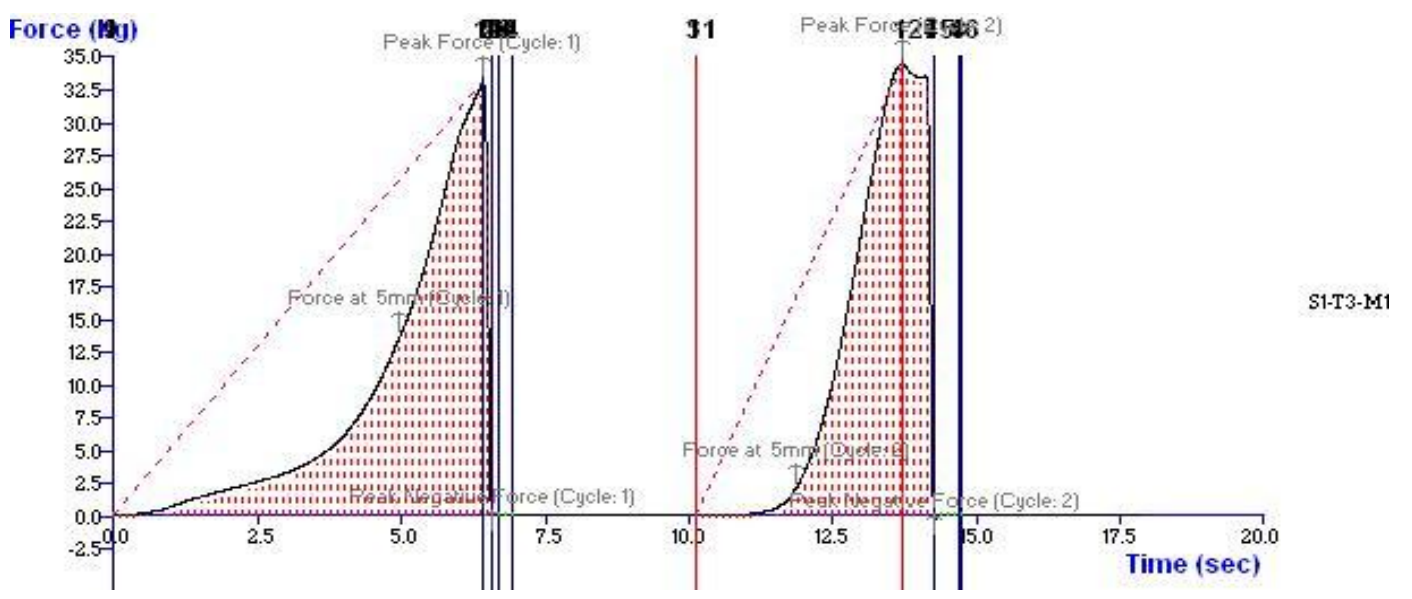

Fig.21 TPA graph aonla candy $\left(\mathrm{S}_{1} \mathrm{~T}_{3} \mathrm{M}_{2}\right)$

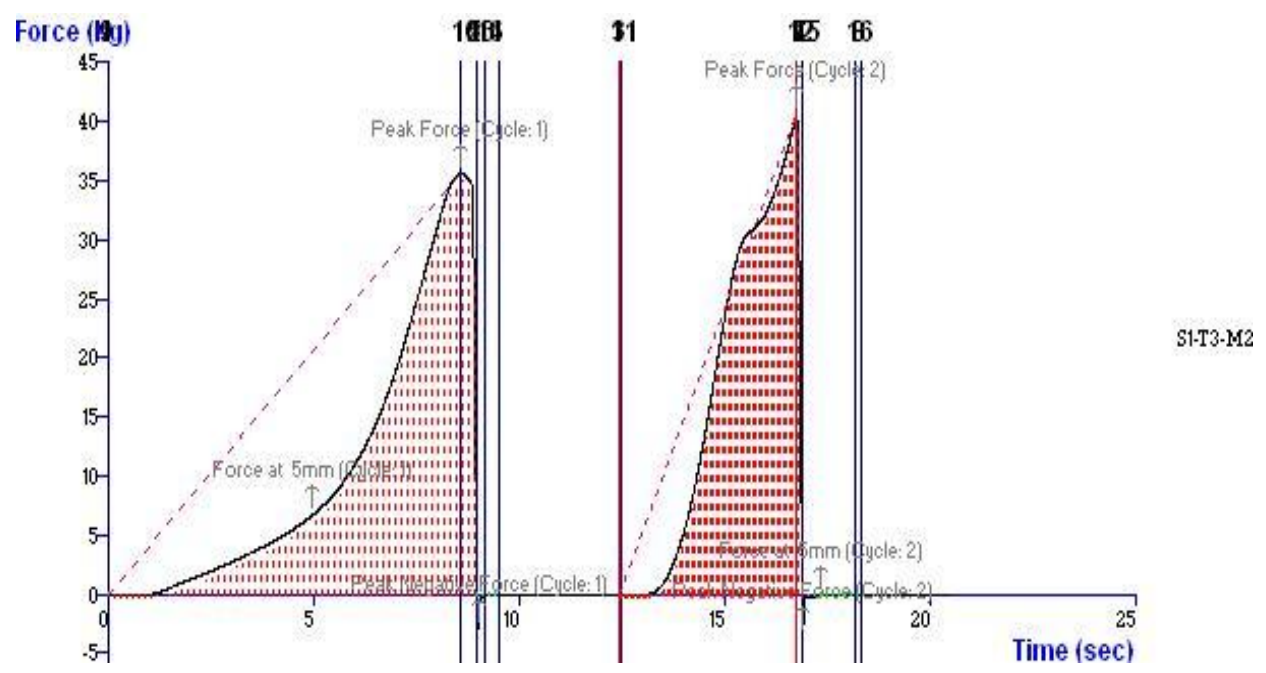


Fig.22 TPA graph aonla candy $\left(\mathrm{S}_{1} \mathrm{~T}_{3} \mathrm{M}_{3}\right)$

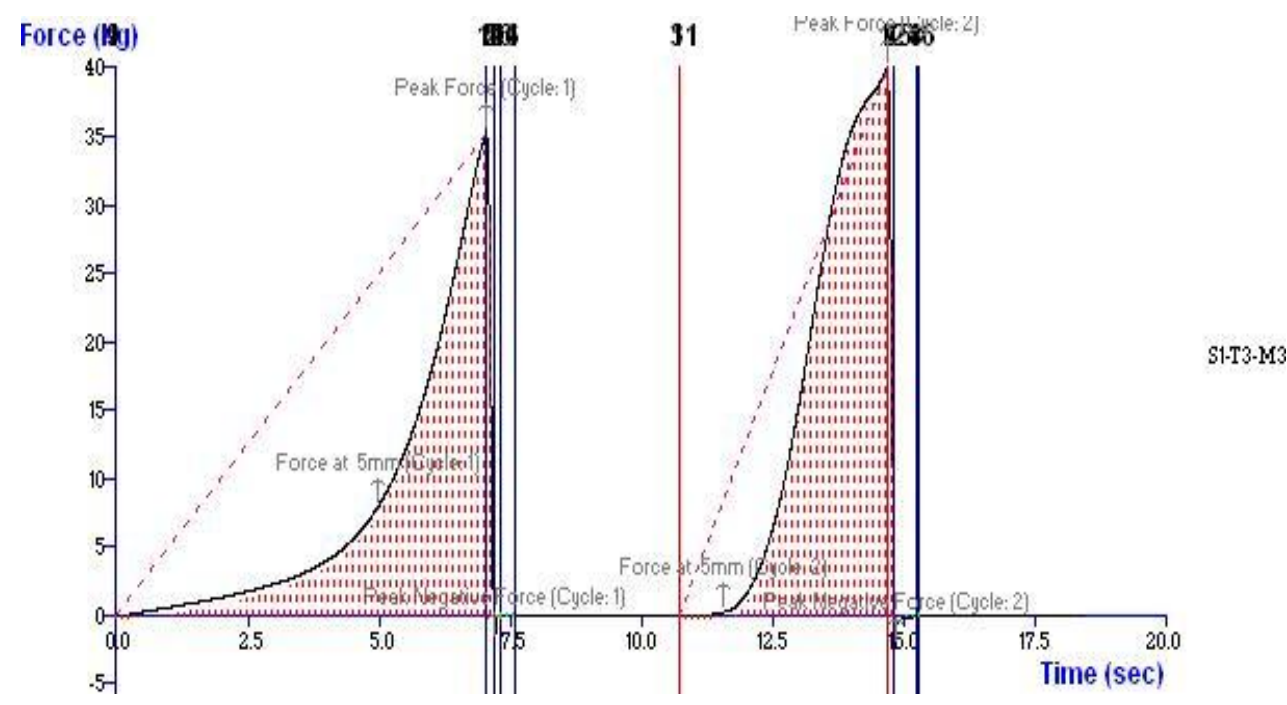

Fig.23 TPA graph aonla candy $\left(\mathrm{S}_{2} \mathrm{~T}_{1} \mathrm{M}_{1}\right)$

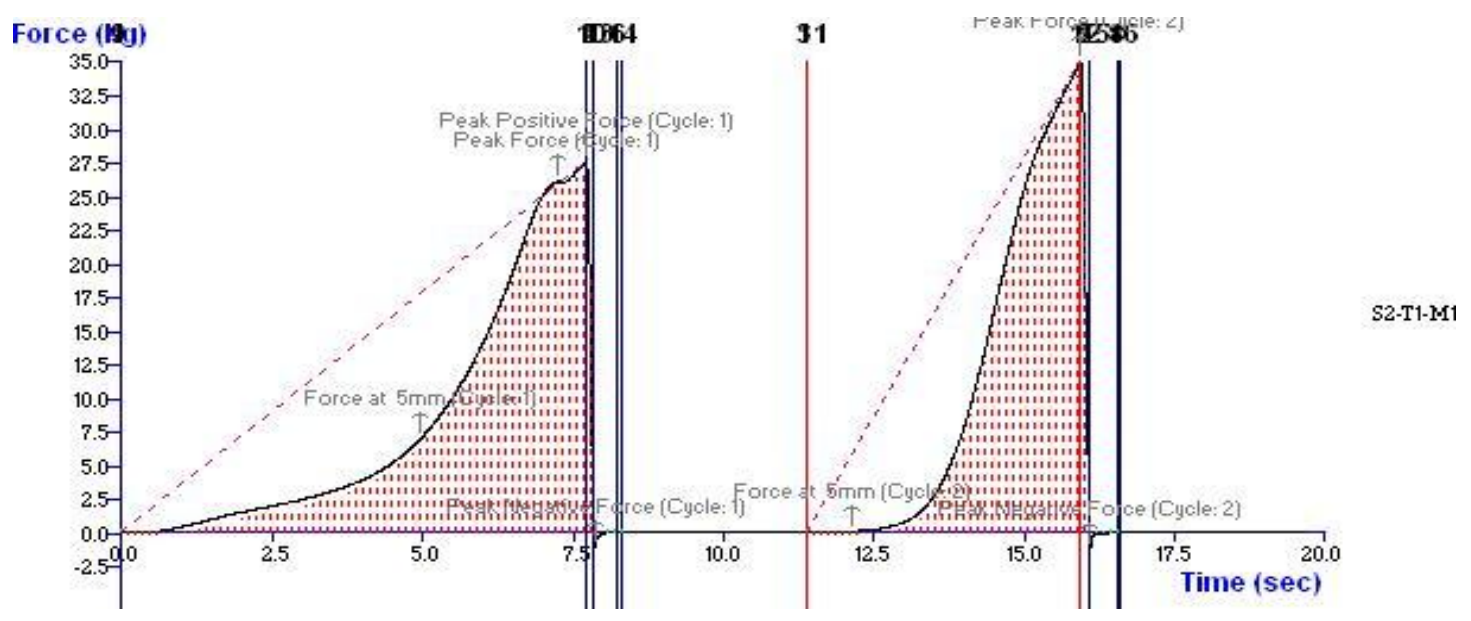

Fig.24 TPA graph aonla candy $\left(\mathrm{S}_{2} \mathrm{~T}_{1} \mathrm{M}_{2}\right)$

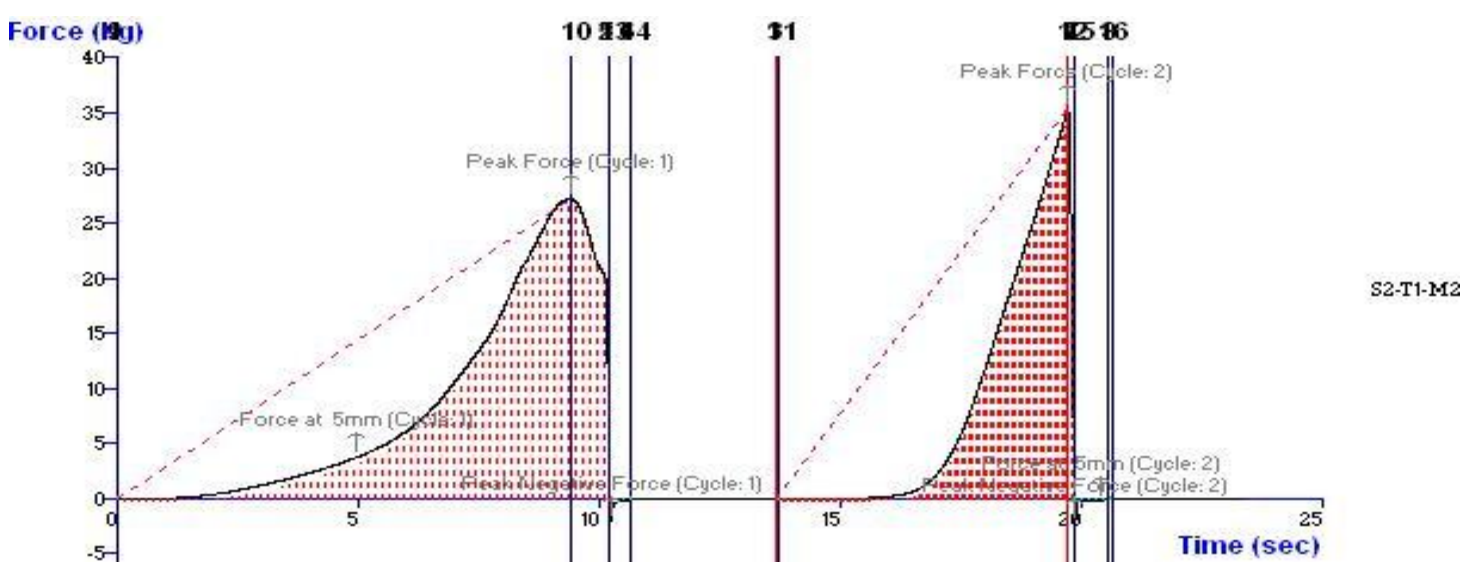


Fig.25 TPA graph aonla candy $\left(\mathrm{S}_{2} \mathrm{~T}_{1} \mathrm{M}_{3}\right)$

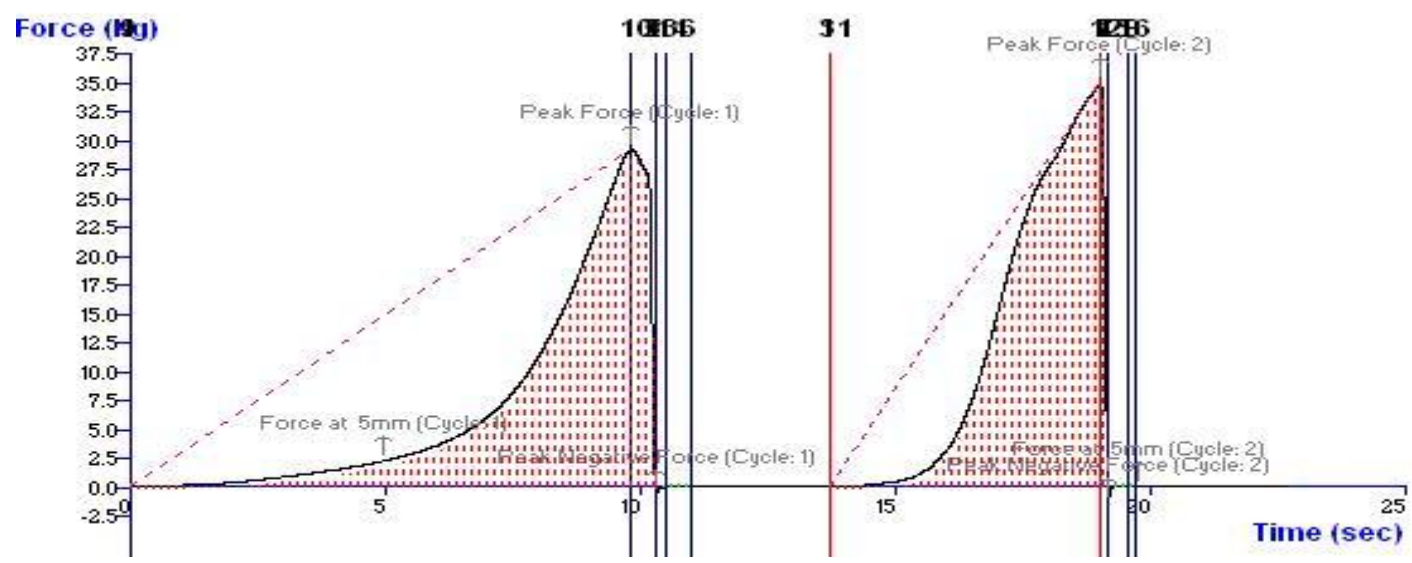

S2-T1-M3

Fig.26 TPA graph aonla candy $\left(\mathrm{S}_{2} \mathrm{~T}_{2} \mathrm{M}_{1}\right)$

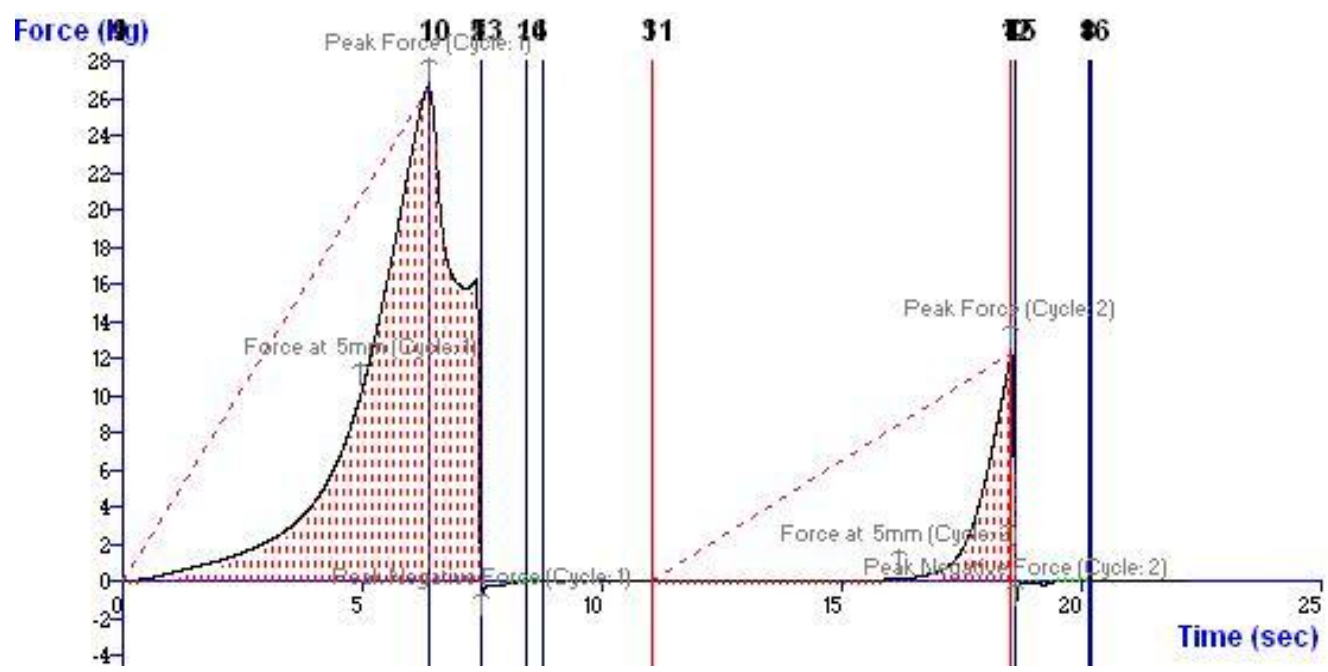

S2-T2-M1

Fig.27 TPA graph aonla candy $\left(\mathrm{S}_{2} \mathrm{~T}_{2} \mathrm{M}_{2}\right)$

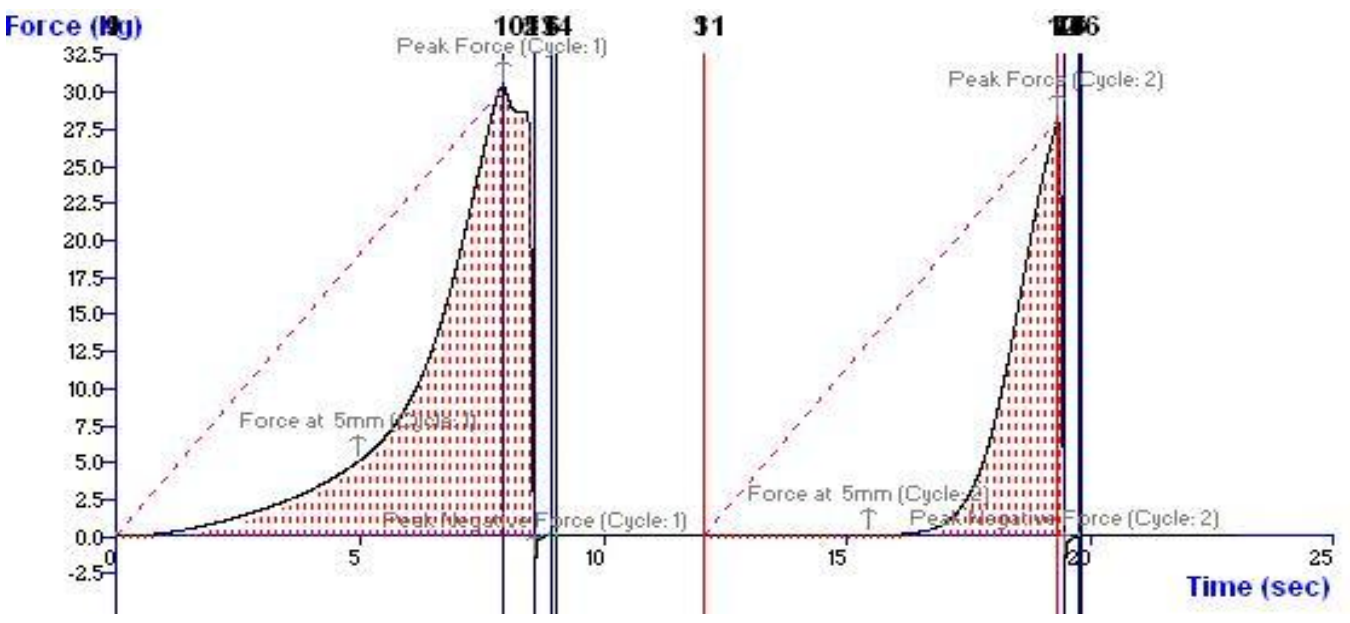


Fig.28 TPA graph aonla candy $\left(\mathrm{S}_{2} \mathrm{~T}_{2} \mathrm{M}_{3}\right)$

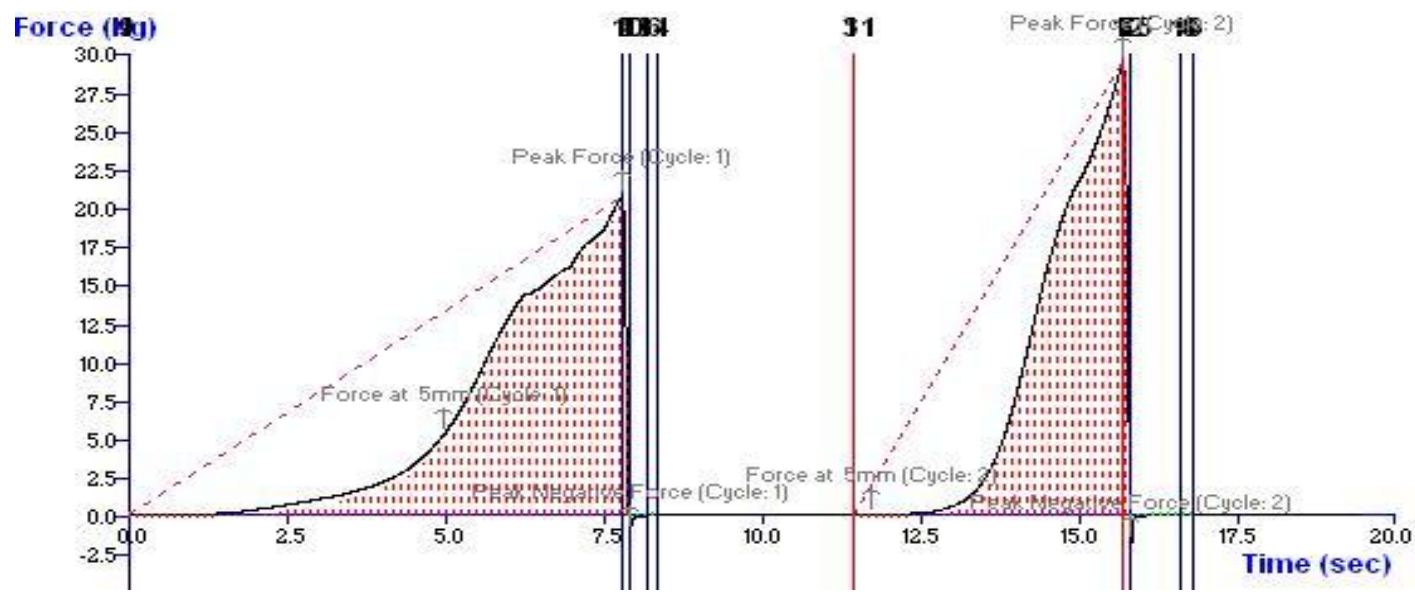

Fig.29 TPA graph aonla candy $\left(\mathrm{S}_{2} \mathrm{~T}_{3} \mathrm{M}_{1}\right)$

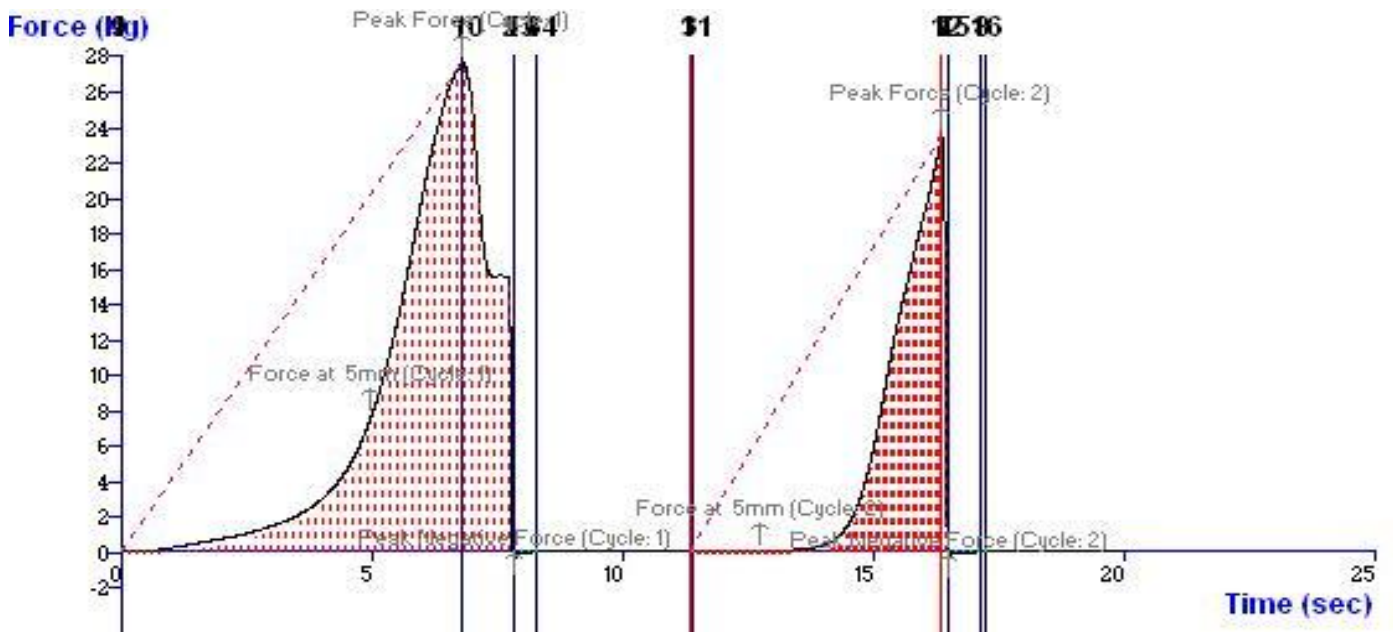

Fig.30 TPA graph aonla candy $\left(\mathrm{S}_{2} \mathrm{~T}_{3} \mathrm{M}_{2}\right)$

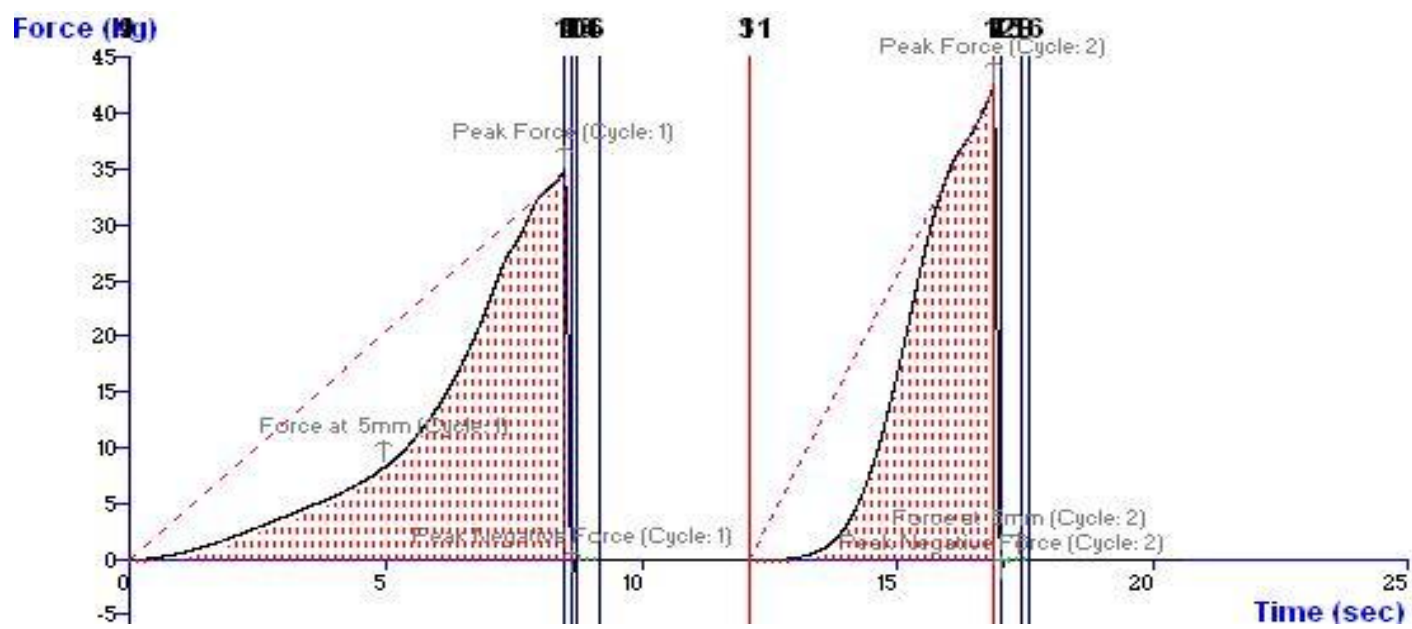

S2-T3-M2 
Fig.31 TPA graph aonla candy $\left(\mathrm{S}_{2} \mathrm{~T}_{3} \mathrm{M}_{3}\right)$

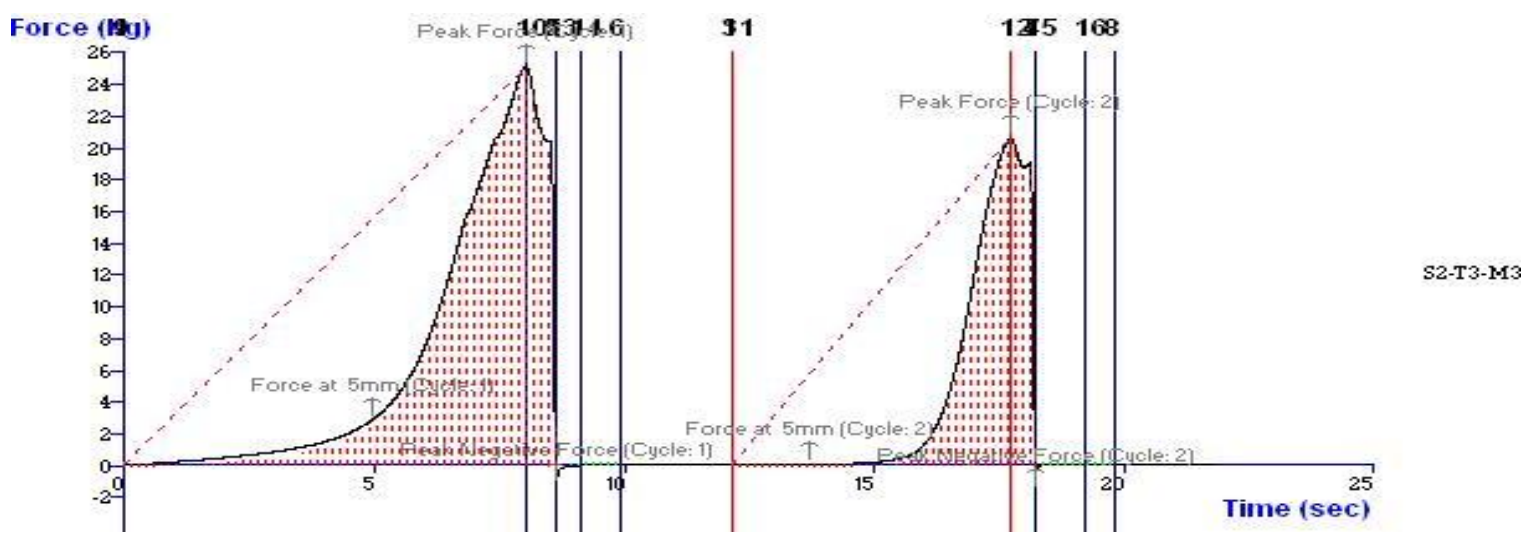

Table.1 Effect of different treatments on Textural Profile of aonla candy

\begin{tabular}{|l|c|c|c|c|c|}
\hline Treatment & Hardness $(\mathbf{k g})$ & Cohesiveness & Springiness & Gumminess (kg) & Adhesiveness (kg) \\
\hline $\mathbf{S}_{\mathbf{1}} \mathbf{T}_{\mathbf{1}} \mathbf{M}_{\mathbf{1}}$ & 30.955 & 1.106 & 1.153 & 34.979 & 0.089 \\
\hline $\mathbf{S}_{\mathbf{1}} \mathbf{T}_{\mathbf{1}} \mathbf{M}_{\mathbf{2}}$ & 39.166 & 1.134 & 1.165 & 44.492 & 0.115 \\
\hline $\mathbf{S}_{\mathbf{1}} \mathbf{T}_{\mathbf{1}} \mathbf{M}_{\mathbf{3}}$ & 29.088 & 1.384 & 1.161 & 40.258 & 0.037 \\
\hline $\mathbf{S}_{\mathbf{1}} \mathbf{T}_{\mathbf{2}} \mathbf{M}_{\mathbf{1}}$ & 26.332 & 0.748 & 1.130 & 19.696 & 0.110 \\
\hline $\mathbf{S}_{\mathbf{1}} \mathbf{T}_{\mathbf{2}} \mathbf{M}_{\mathbf{2}}$ & 43.278 & 0.969 & 1.158 & 41.936 & 0.083 \\
\hline $\mathbf{S}_{\mathbf{1}} \mathbf{T}_{\mathbf{2}} \mathbf{M}_{\mathbf{3}}$ & 26.972 & 0.655 & 1.130 & 17.667 & 0.070 \\
\hline S1T3M1 & 32.999 & 0.899 & 1.127 & 29.666 & 0.042 \\
\hline S1T3M2 & 35.785 & 0.812 & 1.172 & 29.058 & 0.150 \\
\hline S1T3M3 & 35.284 & 1.141 & 1.148 & 40.259 & 0.078 \\
\hline S2T1M1 & 27.618 & 0.834 & 1.137 & 23.033 & 0.102 \\
\hline S2T1M2 & 27.308 & 0.603 & 1.135 & 16.467 & 0.203 \\
\hline S2T1M3 & 29.161 & 0.991 & 1.160 & 28.899 & 0.071 \\
\hline S2T2M1 & 26.627 & 0.140 & 0.996 & 3.728 & 0.297 \\
\hline S2T2M2 & 30.353 & 0.436 & 1.048 & 13.234 & 0.139 \\
\hline S2T2M3 & 20.720 & 0.842 & 1.151 & 17.446 & 0.103 \\
\hline S2T3M1 & 27.577 & 0.407 & 1.118 & 11.224 & 0.120 \\
\hline S2T3M2 & 34.803 & 0.795 & 1.148 & 27.668 & 0.083 \\
\hline S2T3M3 & 25.101 & 0.495 & 1.101 & 12.425 & 0.156 \\
\hline Mean & 30.507 & 0.801 & 1.130 & 25.119 & 0.114 \\
\hline
\end{tabular}

Each value is an average of three determinations

\section{Details of treatments}

\begin{tabular}{|l|l|l|}
\hline $\begin{array}{l}\text { Factor A(S)-Standard of } \\
\text { Sugar Syrup }\end{array}$ & Factor B(T) Dipping Time & $\begin{array}{l}\text { Factor C(M) } \\
\text { Drying Methods }\end{array}$ \\
\hline S1-60\% & T1-36hrs & M1-Sun drying \\
\hline S2-70\% & T2-42hrs & M2-Solar drying \\
\hline & T3-48hrs & M3-Cabinet drying \\
\hline
\end{tabular}




\section{Procurement of raw material}

\begin{tabular}{|c|c|c|}
\hline Treat. No. & Treatment Combination & Treatment Details \\
\hline $\mathbf{T}_{1}$ & $\mathrm{~S}_{1} \mathrm{~T}_{1} \mathrm{M}_{1}$ & $60 \%$ Sugar conc.+ dipping for $36 \mathrm{hrs}+$ sun drying \\
\hline $\mathbf{T}_{2}$ & $\mathrm{~S}_{1} \mathrm{~T}_{1} \mathrm{M}_{2}$ & $60 \%$ Sugar conc.+ dipping for $36 \mathrm{hrs}+$ solar drying \\
\hline $\mathbf{T}_{3}$ & $\mathrm{~S}_{1} \mathrm{~T}_{1} \mathrm{M}_{3}$ & $60 \%$ Sugar conc. + dipping for $36 \mathrm{hrs}+$ cabinet drying \\
\hline $\mathbf{T}_{4}$ & $\mathrm{~S}_{1} \mathrm{~T}_{2} \mathrm{M}_{1}$ & $60 \%$ Sugar conc.+ dipping for $42 \mathrm{hrs}+$ sun drying \\
\hline $\mathbf{T}_{5}$ & $\mathrm{~S}_{1} \mathrm{~T}_{2} \mathrm{M}_{2}$ & $60 \%$ Sugar conc. + dipping for $42 \mathrm{hrs}+$ solar drying \\
\hline $\mathbf{T}_{6}$ & $\mathrm{~S}_{1} \mathrm{~T}_{2} \mathrm{M}_{3}$ & $60 \%$ Sugar conc. + dipping for $42 \mathrm{hrs}+$ cabinet drying \\
\hline $\mathbf{T}_{7}$ & $\mathrm{~S}_{1} \mathrm{~T}_{3} \mathrm{M}_{1}$ & $60 \%$ Sugar conc. + dipping for $48 \mathrm{hrs}+$ sun drying \\
\hline $\mathbf{T}_{8}$ & $\mathrm{~S}_{1} \mathrm{~T}_{3} \mathrm{M}_{2}$ & $60 \%$ Sugar conc. + dipping for $48 \mathrm{hrs}+$ solar drying \\
\hline $\mathbf{T}_{9}$ & $\mathrm{~S}_{1} \mathrm{~T}_{3} \mathrm{M}_{3}$ & $60 \%$ Sugar conc. + dipping for $48 \mathrm{hrs}+$ cabinet drying \\
\hline$T_{10}$ & $\mathrm{~S}_{2} \mathrm{~T}_{1} \mathrm{M}_{1}$ & $70 \%$ Sugar conc. + dipping for $36 \mathrm{hrs}+$ sun drying \\
\hline$T_{11}$ & $\mathrm{~S}_{2} \mathrm{~T}_{1} \mathrm{M}_{2}$ & $70 \%$ Sugar conc. + dipping for $36 \mathrm{hrs}+$ solar drying \\
\hline$T_{12}$ & S2T1M3 & $70 \%$ Sugar conc. + dipping for $36 \mathrm{hrs}+$ cabinet drying \\
\hline $\mathbf{T}_{13}$ & $\mathrm{~S}_{2} \mathrm{~T}_{2} \mathrm{M}_{1}$ & $70 \%$ Sugar conc. + dipping for $42 \mathrm{hrs}+$ sun drying \\
\hline$T_{14}$ & $\mathrm{~S}_{2} \mathrm{~T}_{2} \mathrm{M}_{2}$ & $70 \%$ Sugar conc. + dipping for $42 \mathrm{hrs}+$ solar drying \\
\hline $\mathbf{T}_{15}$ & $\mathrm{~S}_{2} \mathrm{~T}_{2} \mathrm{M}_{3}$ & $70 \%$ Sugar conc. + dipping for $42 \mathrm{hrs}+$ cabinet drying \\
\hline$T_{16}$ & $\mathrm{~S}_{2} \mathrm{~T}_{3} \mathrm{M}_{1}$ & $70 \%$ Sugar conc. + dipping for $48 \mathrm{hrs}+$ sun drying \\
\hline $\mathbf{T}_{17}$ & $\mathrm{~S}_{2} \mathrm{~T}_{3} \mathrm{M}_{2}$ & $70 \%$ Sugar conc. + dipping for $48 \mathrm{hrs}+$ solar drying \\
\hline$T_{18}$ & $\mathrm{~S}_{2} \mathrm{~T}_{3} \mathrm{M}_{3}$ & $70 \%$ Sugar conc. + dipping for $48 \mathrm{hrs}+$ cabinet drying \\
\hline
\end{tabular}

Cohesiveness refers to the strength of internal bonds that keeps the sample cohesive. The lowest value of cohesiveness (0.140) was observed in treatment $\mathrm{S}_{2} \mathrm{~T}_{2} \mathrm{M} 1 \quad(70 \%$ sugar syrup concentration, $48 \mathrm{hr}$. dipping time and sun dryer) followed by in treatment $\mathrm{S}_{2} \mathrm{~T}_{3} \mathrm{M}_{1}$ (70\% sugar syrup concentration, 48 hours. dipping time and sun dryer) i.e. 0.407 whereas treatment $\mathrm{S}_{1} \mathrm{~T}_{1} \mathrm{M}_{3}$ (60\% sugar syrup concentration, $36 \mathrm{hr}$. dipping time and cabinet drying) showed highest value of cohesiveness (1.384). The mean value of cohesiveness of aonla candy was 0.801 .

Springiness is how well a product physically springs back after it has been deformed during the first compression. The highest springiness value (1.172) was found in $\mathrm{S}_{1} \mathrm{~T}_{3} \mathrm{M}_{2}(60 \%$ sugar syrup concentration, $48 \mathrm{hr}$. dipping time and solar dryer), whereas the least in $\mathrm{S}_{2} \mathrm{~T}_{2} \mathrm{M}_{1}$ (70\% sugar syrup concentration, $42 \mathrm{hr}$. dipping time and sun drying) i.e. 0.996.The mean value of springiness of aonla candy was 1.130 .

Moreover, adhesiveness was found to be highest in treatment $\mathrm{S}_{2} \mathrm{~T}_{2} \mathrm{M}_{1}$ (0.297) whereas the least adhesiveness was found in treatment $\mathrm{S}_{1} \mathrm{~T}_{1} \mathrm{M}_{3}(0.037)$.

The objectives of investigation were to study the effect of concentration of sugar syrup, period of dipping and various drying methods for preparation of aonla candy. The treatment $\mathrm{S}_{1} \mathrm{~T}_{2} \mathrm{M}_{2}$ showed the highest values for hardness $(43.278 \mathrm{~kg})$. The hardness was found to be less in treatment $S_{2} T_{2} M_{3}(20.720$ kg.). The treatment $S_{2} T_{1} M_{3}$ showed lowest value of cohesiveness (0.991) and treatment $\mathrm{S}_{1} \mathrm{~T}_{1} \mathrm{M}_{1}$ showed the highest value (1.106). The highest springiness value (1.172) was found in $S_{1} T_{3} M_{2}$ and treatment $S_{2} T_{2} M_{1}$ showed lowest value i.e.0.996. Moreover, adhesiveness was found to be highest in 
treatment $\mathrm{S}_{2} \mathrm{~T}_{2} \mathrm{M}_{1}$ ) i.e. 0.297 and least in treatment $\mathrm{S}_{1} \mathrm{~T}_{1} \mathrm{M}_{3}$ i.e. 0.037 .

\section{References}

Anonymous. http://www.nhb.gov.in on 16th September, 2015.

Bhattacherjee AK, Chaurasia R, Tandon DK. Quality evaluation of aonla powder obtained by different drying techniques. Progressive Horticulturae. 2012; 44(1): 110-115.

Bose TK, Mitra SK, Sanyal D. Aonla. In: Fruits: Tropical and Subtropical. TK Bose, SK Mitra, D Sanyal (eds.), NayaUdyog Publishers, Calcutta. 2002, 523-538.

Ganachari A, Thangavel K, Mazara AS, Nidoni U, Ananthacharya. Physical properties of Aonla fruit relevant to the design of processing equipments. International Journal of Engineering Science and Technology. 2010; 2(12): $7562-7566$.

Kumar S, Nath V. Storage stability of aonla fruits - A comparative study of zero energy cool chamber versus room temperature. Journal of Food Science and Technology. 1993; 30(3): 202-203.

Kumar, S. and Singh, I.S. 2001. Storage studies of aonla fruit products at ambient temperature. Progressive Horticulturae, 33(2): 169-173.

Nath V, Singh IS, Kumar S. Evaluation of aonla cultivars for their shelf-life at ambient temperature. Narendra Deva Journal of Agricultural Research. 1992; 7(1):117.

Panse, V.S. and P.V. Sukhatkme (1967).Statistical Methods for Agricultural Workers. ICAR, New Delhi.

Pareek S, Kaushik RA. Effect of dryning methods on quality of Indian gooseberry (Emblica officinalis Gaertn.) powder during storage. Journal of Scientific and Industrial Research. 2012; 71(11): 727-732.

Parmar C, Kaushal MK. Wild Fruit of Subhimalayan Region. Kalayani Publisher, New Delhi. 1982, 136.

Priya MD, Khatkar BS. Effect of processing method on keeping quality of aonla preserve. International Food Research Journal. 2013; 20(2): 617-622.

Radha T, Mathew L. Aonla In: Fruit Crops. K.V. Peter (eds.), New Delhi Publishing Agency, New Delhi, 2007; 3: 287-301.

Ranganna S. Handbook of analysis and quality control for fruit and vegetable products. Tata McGraw Hill, New Delhi. 2009, 1112.

Tondon D. K. Yadav R.C. Sood S. Kumar S. and Dikshit A. (2003) Effect of blanching and lye peeling of aonla candy. Indian Food Packer, 57(6): 147152.

\section{How to cite this article:}

Ghanwat Archana, B., V.S. Khandare and Syed, S.J. 2019. Influence of Various Treatments on Textural Profile Analysis of Indian Gooseberry (Emblica officinalis) Candy during Storage. Int.J.Curr.Microbiol.App.Sci. 8(08): 30-46. doi: https://doi.org/10.20546/ijcmas.2019.808.005 